\title{
Steroid Sensitive Nephrotic Syndrome: Revised Guidelines
}

\author{
Aditi Sinha, ${ }^{1}$ Arvind Bagga, ${ }^{1}$ Sushmita BanerJee, ${ }^{2}$ Kirtisudha Mishra, ${ }^{3}$ Amarjeet Mehta, ${ }^{4}$ Indira \\ Agarwal, ${ }^{5}$ Susan Uthup, ${ }^{6}$ AbhiJeet Saha, ${ }^{7}$ OM Prakash Mishra ${ }^{8}$ and Expert Group Of Indian Society of \\ Pediatric Nephrology* \\ From ${ }^{1}$ Division of Nephrology, Departments of Pediatrics, All India Institute of Medical Sciences, New Delhi; ${ }^{2}$ Institute of Child \\ Health, Kolkata; ${ }^{3}$ Chacha Nehru Bal Chikitsalaya, Delhi; ${ }^{4}$ Sawai Man Singh Medical College, Jaipur, ${ }^{5}$ Christian Medical College, \\ Vellore; ${ }^{6}$ Trivandrum Medical College, Thiruvananthapuram; ${ }^{7}$ Lady Hardinge Medical College, New Delhi; ${ }^{8}$ Institute of Medical \\ Sciences, Benaras Hindu University, Varanasi, India. *List of expert group members provided in Annexure I. \\ Correspondence to: Dr. Arvind Bagga, Division of Nephrology, Department of Pediatrics, All India Institute of Medical Sciences, \\ Ansari Nagar, New Delhi 110029, India. arvindbagga@hotmail.com
}

Justification: Steroid sensitive nephrotic syndrome (SSNS) is one of the most common chronic kidney diseases in children. These guidelines update the existing Indian Society of Pediatric Nephrology recommendations on its management. Objective: To frame revised guidelines on diagnosis, evaluation, management and supportive care of patients with the illness. Process: The guidelines combine evidence-based recommendations and expert opinion. Formulation of key questions was followed by review of literature and evaluation of evidence by experts in two face-to-face meetings. Recommendations: The initial statements provide advice for evaluation at onset and follow up and indications for kidney biopsy. Subsequent statements provide recommendations for management of the first episode of illness and of disease relapses. Recommendations on the use of immunosuppressive strategies in patients with frequent relapses and steroid dependence are accompanied by suggestions for step-wise approach and plan of monitoring. Guidance is also provided regarding the management of common complications including edema, hypovolemia and serious infections. Advice on immunization and transition of care is given. The revised guideline is intended to improve the management and outcomes of patients with SSNS, and provide directions for future research.

Keywords: Calcineurin inhibitors, Frequent relapses, Levamisole, Minimal change nephrotic syndrome, Mycophenolate mofetil, Rituximab, Steroid dependence.

Published online: March 20, 2021; PII: S097475591600301

$\mathrm{N}$ ephrotic syndrome, characterized by edema, heavy proteinuria $\left(>1 \mathrm{~g} / \mathrm{m}^{2}\right.$ daily; $>40 \mathrm{mg} / \mathrm{m}^{2} /$ hr) and hypoalbuminemia (serum albumin $<3 \mathrm{~g} / \mathrm{dL}$ ), is among the most common kidney diseases in childhood. The condition has an annual incidence ranging from 1.2 to 16.9 per 100,000 children $[1,2]$. While nephrotic syndrome is usually primary or idiopathic, evaluation might reveal an underlying systemic illness in $5-10 \%$ of patients. Kidney biopsy reveals minimal change disease in $\sim 80 \%$ patients, and focal segmental glomerulosclerosis (FSGS) and mesangioproliferative glomerulonephritis (GN) in 7-8\% each. Therapy with prednisolone results in complete remission of proteinuria in $85-90 \%$ patients, termed steroid sensitive nephrotic syndrome (SSNS). While the outcome in patients with SSNS is satisfactory, approximately $50 \%$ show frequent relapses or steroid dependence, and $3-10 \%$ show late steroid resistance [3-5].

\section{OBJECTIVE}

Guidelines on management of SSNS, by the Indian Society of Pediatric Nephrology, were first published in 2001 [6] and updated in 2008 [7]. With increasing availability of evidence on various therapies, these guidelines have been revised. Guidance is based on the strength and quality of evidence using the GRADE model proposed by the American Academy of Pediatrics [8]. Ungraded statements (indicated by X) are like practice points, not supported by sufficient evidence. Table I highlights key changes in present guidelines compared to 2008 [7] and those recently proposed by the Kidney Disease Improving Global Outcomes [9].

\section{PROCESS}

Workgroups were constituted to address key issues, including: (i) Evaluation at baseline and follow up, role of biopsy, genetic testing, and differential diagnosis; (ii) Management of the initial episode and subsequent relapses; (iii) Management of frequent relapses; and (iv) Supportive care and outcomes. Separate workgroups have addressed guidelines on the definition and management of steroid resistant nephrotic syndrome [10]. The workgroups identified gaps in knowledge, formulated questions and developed consensus statements prior to the meeting in New Delhi on 5 April 2019, when the evidence was discussed through alternating breakout and plenary sessions. Research studies were rated from $A$ to $D$ using standard criteria, and 
Table I Comparison Between Present and 2008 [7] Guidelines of the Indian Society of Pediatric Nephrology (ISPN), and Kidney Disease Improving Global Outcomes (KDIGO) 2021 [9]

\begin{tabular}{|c|c|c|c|}
\hline Parameter & $I S P N 2021$ & $I S P N 2008$ [7] & KDIGO 2021 [9] \\
\hline Nephrotic syndrome & $\begin{array}{l}\text { Nephrotic range proteinuria, } \\
\text { hypoalbuminemia (albumin } \\
<3 \mathrm{~g} / \mathrm{dL} \text { ) and edema }\end{array}$ & $\begin{array}{l}\text { Nephrotic range proteinuria, } \\
\text { hypoalbuminemia }(<2.5 \mathrm{~g} / \mathrm{dL}) \text {, } \\
\text { cholesterol }>200 \mathrm{mg} / \mathrm{dL} \text { and } \\
\text { edema }\end{array}$ & $\begin{array}{l}\text { Nephrotic range proteinuria } \\
\text { and either hypoalbuminemia } \\
(<3 \mathrm{~g} / \mathrm{dL}) \text { or edema }\end{array}$ \\
\hline Steroid resistance & $\begin{array}{l}\text { Lack of complete remission } \\
\text { despite daily therapy with pre- } \\
\text { dnisolone for 6-wk }\end{array}$ & $\begin{array}{l}\text { Lack of complete remission } \\
\text { despite daily therapy with pre- } \\
\text { dnisolone for 4-wk }\end{array}$ & $\begin{array}{l}\text { Lack of complete remission } \\
\text { despite daily therapy with } \\
\text { prednisone for } 4 \text {-weeks }{ }^{a}\end{array}$ \\
\hline $\begin{array}{l}\text { Prednisolone for } \\
\text { initial episode }\end{array}$ & $\begin{array}{l}\text { 6-wk daily and 6-wk AD; sur- } \\
\text { face area (BSA) or weight- } \\
\text { based dosing } b \text {; no indication } \\
\text { for prolonged therapy }\end{array}$ & $\begin{array}{l}6 \text {-wk daily and } 6 \text {-wk AD; } \\
\text { weight-based dosing } b \text {; no indi- } \\
\text { cation for prolonged therapy }\end{array}$ & $\begin{array}{l}\text { 4-6 wk daily and 4-6 wk AD; } \\
\text { BSA or weight-based dosing } \\
\text { prolong therapy (16- } 24 \mathrm{wk} \text { ) if }<4-6 \\
\text { yr-old, or if delayed remission }\end{array}$ \\
\hline Frequent relapses & $\begin{array}{l}\geq 2 \text { relapses in first } 6 \text {-months } \\
\text { after initial therapy; } \geq 3 \text { relapses } \\
\text { in any } 6 \text {-mo; } \geq 4 \text { relapses in } 1 \text { year }\end{array}$ & $\begin{array}{l}\geq 2 \text { relapses in first } 6 \text {-months } \\
\text { after stopping initial therapy; } \\
\geq 4 \text { relapses in } 1 \text {-year }\end{array}$ & $\begin{array}{l}\geq 2 \text { relapses in } 6 \text {-months; } \\
\geq 4 \text { relapses in } 1 \text {-year }\end{array}$ \\
\hline $\begin{array}{l}\text { Prolonged AD } \\
\text { prednisolone }\end{array}$ & $\begin{array}{l}\text { Taper to } 0.5-0.7 \mathrm{mg} / \mathrm{kg} \mathrm{AD} \text { for } \\
6-12 \text { months }\end{array}$ & $\begin{array}{l}\text { Taper to } 0.5-0.7 \mathrm{mg} / \mathrm{kg} \mathrm{AD} \text {, } \\
\text { for } 9-18 \text { months }\end{array}$ & $\begin{array}{l}\text { Limited role in view of risk of } \\
\text { toxicity }\end{array}$ \\
\hline $\begin{array}{l}\text { Prednisolone during } \\
\text { infections }\end{array}$ & $\begin{array}{l}\text { Daily for } 5-7 \text { days, if receiving } \\
\text { AD prednisolone }\end{array}$ & No recommendation & $\begin{array}{l}\text { Daily at } 0.5 \mathrm{mg} / \mathrm{kg} \text { for } 5-7 \\
\text { days, whether on/off steroids }\end{array}$ \\
\hline $\begin{array}{l}\text { Steroid sparing therapy: } \\
\text { Indications, choice }\end{array}$ & $\begin{array}{l}\text { Failure of AD therapy: } \\
\text { Levamisole or MMF } \\
\text { Steroid threshold }>1 \mathrm{mg} / \mathrm{kg} \mathrm{AD} \text {, } \\
\text { toxicity, complicated relapses: } \\
\text { Cyclophosphamide, MMF } \\
\text { Difficult-to-treat: CNI, then } \\
\text { rituximab }\end{array}$ & $\begin{array}{l}\text { Failure of AD therapy, steroid } \\
\text { toxicity: Levamisole } \\
\text { Steroid toxicity, severe } \\
\text { relapses, poor compliance: } \\
\text { Cyclophosphamide } \\
\text { Failure of above therapies: } \\
\text { CNI; MMF an option }\end{array}$ & $\begin{array}{l}\text { Frequent relapses with steroid } \\
\text { toxicity; patients with dependence } \\
\text { Frequent relapses: Levamisole, } \\
\text { cyclophosphamide } \\
\text { Dependence: MMF, rituximab, } \\
\text { cyclophosphamide, CNI }\end{array}$ \\
\hline
\end{tabular}

Supportive

Advice on diet, immunization, management of edema; calcium and vitamin D supplements

AD-alternate days; CNI-calcineurin inhibitor; $M M F$-mycophenolate mofetil; ${ }^{a}$ Late responder: Partial remission at 4 weeks and complete remission at 6 weeks of daily prednisone; ${ }^{b} B S A$-based dosing: $60 \mathrm{mg} / \mathrm{m}^{2}$ daily and $40 \mathrm{mg} / \mathrm{m}^{2} \mathrm{AD}$; weight-based: $2 \mathrm{mg} / \mathrm{kg} /$ day and $1.5 \mathrm{mg} / \mathrm{kg} \mathrm{AD} ; \mathrm{maximum} 60$ $m g$ daily and $40 \mathrm{mg} A D$.

each consensus statement was assigned one of two levels of recommendation, based on assessment of relative benefit versus harm, and relevance in context of availability and cost, and the feasibility of monitoring (Supp. Table I) [11]. Draft guidelines were again discussed in Pune on 21 December 2019. The final manuscript was circulated to all participants for approval.

\section{DEFINITIONS}

Criteria for defining the course of nephrotic syndrome are shown in Box I [12-14]. For purpose of this guidelines, unless stated, the term 'frequent relapses' includes patients with 'steroid dependence', and prednisolone and prednisone are used interchangeably. The management of initial and late resistance, defined as lack of remission following 6-weeks' prednisolone therapy (Box I) is discussed separately [10].

Patients with frequent relapsing and steroid resistant nephrotic syndrome are at high risk of complications, due to the illness and toxicity of medications. We advise that these patients, and those younger than one year, be managed by pediatric nephrologists.

\section{Guideline 1: Evaluation}

1.1 In a patient presenting with recent onset of edema, we recommend the following investigations to confirm the diagnosis of nephrotic syndrome: (i) urinalysis; and (ii) blood levels of urea, creatinine, albumin and total cholesterol (Box II).

1.2 We suggest additional evaluation in selected patients (Box II).

1.3 We recommend that parents be taught to maintain a record of proteinuria (by dipstick or boiling), infections and medications received.

\section{Rationale}

Children with the first episode of nephrotic syndrome require evaluation to confirm the diagnosis and screen for 


\begin{tabular}{|c|c|}
\hline & Box I Definitions of Disease Course and Severity in Nephrotic Syndrome \\
\hline Nephrotic range proteinuria & $\begin{array}{l}\text { Urine protein } 3+\text { or } 4+\text {; urine protein to creatinine ratio }(\mathrm{Up} / \mathrm{Uc})>2 \mathrm{mg} / \mathrm{mg} \text { in first morning urine specimen; } \\
\text { proteinuria }>40 \mathrm{mg} / \mathrm{m}^{2} / \mathrm{hr}\end{array}$ \\
\hline Remission & Urine protein nil or trace $(\mathrm{Up} / \mathrm{Uc}<0.2 \mathrm{mg} / \mathrm{mg})$ for 3 consecutive early morning specimens \\
\hline Relapse & $\begin{array}{l}\text { Urine protein } \geq 3+(\mathrm{Up} / \mathrm{Uc}>2 \mathrm{mg} / \mathrm{mg}) \text { for } 3 \text { consecutive early morning specimens, having been in remission } \\
\text { previously }\end{array}$ \\
\hline Frequent relapses & $\begin{array}{l}\text { Two or more relapses in the first 6-months after stopping initial therapy }{ }^{\mathrm{a}} ; \geq 3 \text { relapses in any 6-months; or } \geq 4 \\
\text { relapses in one yr }\end{array}$ \\
\hline Steroid dependence & Two consecutive relapses when on alternate day steroids, or within 14 days of its discontinuation \\
\hline Steroid resistance ${ }^{\mathrm{b}}$ & $\begin{array}{l}\text { Lack of complete remission despite therapy with daily prednisolone at a dose of } 2 \mathrm{mg} / \mathrm{kg} \text { ( or } 60 \mathrm{mg} / \mathrm{m}^{2} \text { ) daily for } \\
6 \text { weeks }\end{array}$ \\
\hline Stable remission & Sustained remission or infrequent relapses during immunosuppressive therapy \\
\hline Complicated relapse & $\begin{array}{l}\text { Relapse associated with life-threatening complications: (i) hypovolemia requiring inpatient care, (ii) severe } \\
\text { infection (peritonitis, cellulitis, meningitis), or (iii) thrombosis }\end{array}$ \\
\hline Significant steroid toxicity & $\begin{array}{l}\text { Hyperglycemia (fasting glucose }>100 \mathrm{mg} / \mathrm{dL} \text {, post-prandial glucose }>140 \mathrm{mg} / \mathrm{dL} \text {, or HbA1c }>5.7 \% \text { ) [12]; obesity } \\
\text { (body mass index }>\text { equivalent of } 27 \mathrm{~kg} / \mathrm{m}^{2} \text { in adults [13]); short stature (height }<-2 \text { SDS for age [13]) with height } \\
\text { velocity ( }<-3 \text { SDS for age [14]); raised intraocular pressure; cataract(s); myopathy; osteonecrosis; or psychosis }\end{array}$ \\
\hline $\begin{array}{l}\text { Difficult-to-treat steroid } \\
\text { sensitive disease }\end{array}$ & $\begin{array}{l}\text { Both of the following: (i) frequent relapses, or significant steroid toxicity with infrequent relapses; and (ii) failure } \\
\text { of } \geq 2 \text { steroid sparing agents (including levamisole, cyclophosphamide, mycophenolate mofetil) }\end{array}$ \\
\hline
\end{tabular}

an underlying cause and complications. Family history of nephrotic syndrome, asthma and allergies, and renal diseases are asked for. Features including fever, abdominal pain, rash, arthralgia, oliguria, hematuria and history of drugs or infections suggest an underlying cause, e.g., systemic lupus erythematosus and IgA vasculitis. Height, weight and blood pressure should be recorded; weight monitoring helps in assessment for edema.

Investigations advised at the initial episode are listed in Box II. The diagnosis is based on presence of nephrotic range proteinuria, hypoalbuminemia and edema. Majority of patients show total cholesterol levels exceeding $200 \mathrm{mg} /$ $\mathrm{dL}$. Nephrotic range proteinuria is present if in an early morning urine sample protein is 3-4+ (dipstick/ boiling test), spot protein to creatinine ratio is $>2 \mathrm{mg} / \mathrm{mg}$, or the protein excretion is $>40 \mathrm{mg} / \mathrm{m}^{2}$ per hr. Precise estimation of 24-hr protein excretion is cumbersome, and is seldom necessary. Urine microscopy is normal, except for hyaline or granular casts; occasional microscopic hematuria is not uncommon. Persistent microscopic hematuria or red cell casts suggests disease other than minimal change nephrotic syndrome, like infection related GN, C3 glomerulopathy, systemic lupus or vasculitis [1]. Additional investigations are required for their diagnosis. Since patients with nephrotic syndrome do not have increased prevalence of urinary tract infections, routine urine cultures are not necessary.

With an estimated prevalence of bacteriologically positive pulmonary tuberculosis of 296 per 100,000 population in India, the risk of latent tuberculosis infection in childhood is high $[15,16]$. Tuberculin test is suggested prior to the first course of steroid treatment, especially with history of contact [16]. Chest radiography is done in patients with positive tuberculin test; those with features of tuberculosis require appropriate therapy. Patients with positive tuberculin reaction, but no radiological or bacteriological evidence of tuberculosis, should receive isoniazid prophylaxis for 6-months [16]. The prevalence of hepatitis B in non-tribal Indian populations is low $(2.4 \%$; $95 \% \mathrm{CI}, 2.2-2.7 \%$ ) [17], and routine screening is not required.

Genome wide association studies have identified variants in multiple MHC class II molecules as risk factors for SSNS [18]. The diagnostic and prognostic utility of various biomarkers of minimal change disease is limited [19]. There is, currently, no role for biomarkers or genetic studies in these patients.

\section{Subsequent Evaluation}

Parents are instructed to monitor the child's urine at home, using dipstick or boiling test, and are explained the features of a relapse. During remission, they are advised to screen for proteinuria 2-3 times a week; the child is also examined every day during infections, or if edema is present. Frequent assessment of biochemistry is not necessary. Evaluation of patients during relapses also includes screening for complications (Box II).

\section{Guideline 2: Kidney biopsy}

2.1 We recommend kidney biopsy in nephrotic syndrome, 
in the presence of: (i) persistent microscopic hematuria, gross hematuria, or acute kidney injury not attributed to hypovolemia; (ii) systemic features: fever, rash, arthralgia, low complement $\mathrm{C} 3$; (iii) initial or late corticosteroid resistance; and (iv) prolonged (>30-36 months) therapy with calcineurin inhibitors (CNI), or reduced kidney function during their use.

$2.2 \mathrm{We}$ suggest performing kidney biopsy prior to initiating therapy with CNI.

$2.3 \mathrm{We}$ recommend light microscopy and immunofluorescence examination on all kidney biopsies. Electron microscopy is required in patients with gross or persistent microscopic hematuria, low $\mathrm{C} 3$ and suspected disorders of glomerular basement membrane.

(X)

\section{Rationale}

Clinicopathological studies show that kidney biopsy is not routinely required in children with idiopathic nephrotic syndrome prior to therapy with corticosteroids [20-22]. Remission of proteinuria following steroid therapy is the most important predictor of long-term outcome $[3,23]$. The chief indication of kidney biopsy is in patients who fail to show complete remission of

Box II Investigations in Patients with Steroid Sensitive Nephrotic Syndrome

Essential at onset

Urinalysis $^{a}$

Complete blood counts

Blood urea, creatinine, electrolytes, total protein, albumin, total cholesterol

Tuberculin test

Additional evaluation, at onset or relapse

Chest radiography: Positive tuberculin test or history of contact; suspected lower respiratory tract infection

Renal ultrasonography: Planned for kidney biopsy; presence of gross hematuria; suspected renal vein thrombosis

Complete blood counts: Suspected systemic infection or hypovolemia

Blood urea, creatinine, albumin, electrolytes: Severe edema; hypovolemia/dehydration; oliguria/anuria; prolonged ( $>72 \mathrm{~h}$ ) diuretic therapy

Complement C3, C4, antinuclear antibody, antistreptolysin O: Gross, persistent microscopic hematuria; sustained hypertension; suspected secondary cause (systemic lupus, IgA vasculitis, C3 glomerulopathy)

Serum transaminases; hepatitis B surface antigen; antibody against hepatitis $\mathrm{C}$ virus: History of jaundice or liver disease

Periodic monitoring, if relapsing illness

Blood creatinine; albumin, electrolytes

${ }^{a}$ Quantitative estimation of urine protein is required if the diagnosis of nephrotic range proteinuria is uncertain. proteinuria despite 6-weeks daily therapy with prednisolone (steroid resistant illness) [10,24]. A biopsy is indicated in patients with gross hematuria or persistent microscopic hematuria at the onset $>5$ red cells per high power field on 3 or more occasions, in urine centrifuged at $400 \mathrm{~g}$ for 4-5 minutes); or extrarenal features of a systemic disease [20-23,25].

An age of onset of more than 12-years is often cited as an indication for performing a kidney biopsy. Review of literature in adolescent onset nephrotic syndrome suggests that a combination of features, including persistent microscopic hematuria, low $\mathrm{C} 3$ and steroid resistance, detects all patients with membranous nephropathy or proliferative GN [20-22,26,27]. This might obviate the need for a kidney biopsy in adolescents presenting with typical nephrotic syndrome that is steroid sensitive. Since infants ( $<12$-months-old), including those with congenital nephrotic syndrome, are likely to show histological features other than minimal change disease or an underlying genetic change, we advise next-generation sequencing in these patients [10]. Patients with onset of idiopathic nephrotic syndrome beyond infancy should receive therapy with prednisolone, and are advised to undergo kidney biopsy if they show steroid resistance.

The large majority of patients with SSNS show minimal change disease, and less commonly, FSGS or mesangioproliferative GN [20-22,28]. More than 90\% children with minimal change disease, $50 \%$ with mesangioproliferative GN, and 30\% with FSGS have steroid sensitive disease. Patients with frequent relapses do not require a biopsy before initiating therapy with steroidsparing agents like levamisole, cyclo-phosphamide, mycophenolate mofetil (MMF) or rituximab [29]. The exception is prior to the use of CNI.

While there is limited guidance to support kidney biopsy in patients with SSNS prior to the therapy with CNI $[9,30]$, information on the extent of tubular atrophy and interstitial fibrosis is useful when planning therapy. Therapy with CNI might result in acute nephrotoxicity, manifested as acute tubular injury and isometric tubular epithelial vacuolization $[31,32]$. Chronic nephrotoxicity, characterized by striped tubulointerstitial fibrosis has been reported in $25-43 \%$ biopsies following therapy (for 2.5-3.5 years) with cyclosporin or tacrolimus [33-35]. While a recent report found low risk of nephrotoxicity despite prolonged use of tacrolimus [36], most reports suggest similar risk with both medications [34,37]. We therefore suggest considering kidney biopsy before initiating therapy with CNI, particularly in patients with prolonged disease and unclear course, and to inform the clinician regarding baseline histological changes and 
allow appropriate counseling. In view of long-term risks of nephrotoxicity, kidney biopsy should be performed following prolonged therapy with CNI, or if the therapy is associated with decline in eGFR that persists despite reduction in CNI dose [9,38].

An adequate biopsy specimen should preferably include the corticomedullary junction and approximately 20 glomeruli to exclude the diagnosis of FSGS [39]. Apart from renal histology, the biopsy provides information on extent and morphology of glomerulosclerosis and associated tubulointerstitial changes. The diagnosis of IgA nephropathy, C3 glomerulopathy and early membranous nephropathy is suggested by immunofluorescence studies. While kidney biopsies from all patients with nephrotic syndrome should be examined by electron microscopy, the facility is often not available. Ultrastructural examination helps to confirm the diagnosis of minimal change disease (effacement of podocyte foot processes; no electron dense deposits), differentiate primary from secondary FSGS (diffuse versus focal foot process effacement), categorize membranous nephropathy and C3 glomerulopathy, and identify disorders of glomerular basement membrane [40].

\section{Guideline 3: Therapy for the first episode of nephrotic syndrome}

We recommend that therapy for the initial episode should comprise of prednisolone at a dose of $60 \mathrm{mg} / \mathrm{m}^{2} /$ day $(2$ $\mathrm{mg} / \mathrm{kg} /$ day, maximum $60 \mathrm{mg}$ in 1-2 divided doses) for 6 weeks, followed by $40 \mathrm{mg} / \mathrm{m}^{2}(1.5 \mathrm{mg} / \mathrm{kg}$, maximum 40 $\mathrm{mg}$ as single morning dose) on alternate days for the next 6 weeks, and then discontinued.

\section{Rationale}

In 1981, the International Study of Kidney Disease in Children (ISKDC) proposed that the first episode of nephrotic syndrome be treated with daily prednisone for 4-weeks, followed by intermittent therapy for the next 4weeks, and then discontinued [41]. Later, a randomized controlled trial (RCT) by the Arbeitsgemeinschaft für Padiatrische Nephrologie showed that therapy with prednisolone for 6-weeks daily and 6-weeks alternateday was better in terms of reduced incidence of relapses over the next 12-24 months [42]. In efforts to define optimal therapy for the initial episode, several RCTs have investigated the duration and dose of prednisolone, based on which, a meta-analysis, in 2007, concluded that prolonging therapy for 6-months was associated with reduced risk of relapses and of frequent relapses (relative risk, RR 0.55; 95\% CI 0.39-0.80) [43]. However, most studies included in this analysis had methodological flaws, resulting in a high risk of bias.
Four large multicenter RCTs published in the last 7 years have challenged the previous results (Supp. Table II). These studies, representing outcomes in over 800 patients across Netherlands, UK, Japan and India, show that extending initial therapy beyond 8-12 weeks does not influence either the time to first relapse or the risk of frequent relapses at 1-2 years' follow up. These studies had low risk of bias; three were placebo-controlled. A meta-analysis that included three of these studies, showed that the risk of frequent relapses at 1-2 years' follow-up was lower for 3-months or longer versus 2-months therapy (RR 0.68; 95\% CI 0.47-1.0), but not for 5-months or longer versus 3-months therapy (RR 0.78; 95\% CI $0.50-1.22$ ) [44]. Subgroup analysis, limited to studies at low risk of bias, indicated similar risk for frequent relapses in patients treated for 2-3 months versus 3-6 months. These findings are confirmed with inclusion of the PREDNOS study (Supp. Fig. 1) [45]. While post-hoc analyses in two studies suggest a trend for benefit with prolonged therapy in young children, this finding requires confirmation $[45,46]$.

Based on pharmacokinetics and variations by age, prednisolone is preferably dosed by body surface area in children [47]. However, estimation of body surface area involves complex formulae with variable results [48]. Calculation using body weight is convenient, but results in relative underdosing, particularly in young children $[47,49]$. Underdosing, using weight-based calculations, was associated with increased risk of frequent relapses in some [50,51], but not in all studies [52,53]. Experts therefore prefer to administer prednisolone based on body surface area for young children [47].

Daily prednisolone is administered in single or divided-doses, with similar time to remission [54]. There is no evidence to support therapy with preparations other than prednisone or its active metabolite, prednisolone [55]. Use of deflazacort, betamethasone, dexamethasone or methylprednisolone is not advised. Prednisolone is best given following food; therapy with antacids, ranitidine or proton pump inhibitors is not routinely required.

\section{Guideline 4: Therapy of relapses}

We recommend that relapses be treated with prednisolone at $60 \mathrm{mg} / \mathrm{m}^{2} /$ day $(2 \mathrm{mg} / \mathrm{kg} /$ day; maximum $60 \mathrm{mg})$ in single or divided-doses until remission (protein trace/nil for 3 consecutive days), followed by $40 \mathrm{mg} / \mathrm{m}^{2}(1.5 \mathrm{mg} / \mathrm{kg}$, maximum $40 \mathrm{mg}$ ) on alternate days for 4 -weeks.

(1C)

\section{Rationale}

Almost one-half of the relapses are precipitated by minor infections, usually of the upper respiratory tract. 
Treatment of infection may rarely induce remission, avoiding the need for corticosteroid therapy. A relapse has conventionally, albeit empirically, been treated as outlined above, but guidelines vary in the duration of therapy. Remission is achieved by 7-10 days, and daily therapy is seldom necessary beyond 2 weeks. In case of persistent proteinuria, daily therapy with prednisolone may be extended, to maximum of 6-weeks. Lack of remission despite treatment with 6-weeks' daily prednisolone indicates late steroid resistance that requires specific evaluation and management [10].

Dose based on body surface area and weight is associated with similar time to remission and frequency of subsequent relapses [52,53]. Retrospective studies and small RCTs suggest that reduced dose or abbreviated duration of therapy with prednisolone is effective in inducing and maintaining remission (Supp. Table III). Well-powered studies are required to evaluate the optimal dose and duration of prednisolone for relapses.

\section{Guideline 5: Management of frequent relapses and steroid dependence}

\section{Definition}

Frequent relapses are defined by the ISKDC as occurrence of two or more relapses in the first 6-months after initial response, or four or more relapses in a year [3]. These patients are at risk of morbidity associated with multiple relapses and corticosteroid toxicity. The term has been used for over 40-yr, with minor modifications. Additionally, we propose that patients with three or more relapses in any 6months be also classified as frequent relapsers (Box I). Steroid dependence, as previously defined, includes patients with two consecutive relapses, while receiving or within 2-weeks of discontinuing prednisolone $[3,6]$.

The occurrence of two or more relapses in the first 6months is usually associated with high frequency of relapses in the subsequent 12-24 months [3]. Patients experiencing 4 relapses annually receive $\sim 165-200 \mathrm{mg} / \mathrm{kg}$ (4.6-5.6 $\mathrm{g} / \mathrm{m}^{2}$ ) prednisolone, corresponding to $0.45-0.55$ $\mathrm{mg} / \mathrm{kg}\left(12.5-15.5 \mathrm{mg} / \mathrm{m}^{2}\right)$ daily. As 12-weeks' prednisolone therapy for the initial episode $\left(\sim 115 \mathrm{mg} / \mathrm{kg} ; \sim 3.4 \mathrm{~g} / \mathrm{m}^{2}\right)$ might be associated with adverse effects $[55,56]$, the risk of steroid toxicity in patients with 3 relapses in any 6-months or 4 relapses annually is considerable [57].

Two additional situations might suggest the need for steroid-sparing therapy. The first is a patient with significant steroid toxicity (Box I) and fewer relapses (3 relapses/year; 2 relapses in 6-months). The second is the occurrence of two relapses in 6-months during long-term therapy with corticosteroids or steroid-sparing agents. In both instances, it is rational to manage the patients as frequent relapsers, even if they do not satisfy standard definitions. While stable remission (sustained remission or infrequent relapses i.e., upto one relapse in 6-months) during therapy with steroid-sparing agents is acceptable, the definition of failure of therapy depends on the medication, interval between relapses and need for concomitant corticosteroids.

\subsection{Choice of therapy}

We recommend that the choice of immunosuppressive strategy for patients with frequent relapses be based on considerations of its efficacy and adverse effects, patient age, steroid threshold, severity of relapses and features of steroid toxicity (Fig. 1).

\section{Rationale}

In patients with frequent relapses, guidelines recommend that corticosteroid therapy for the relapse be prolonged and tapered over 3 months or longer [9,30,58]. The dose at which relapses occur (steroid threshold) is a marker of disease severity. Prolonged therapy with alternate-day prednisolone might maintain remission in patients with low threshold relapses $(<0.7 \mathrm{mg} / \mathrm{kg}$ on alternate days $)$.

Steroid-sparing interventions are necessary in patients who continue to relapse frequently or show evidence of steroid toxicity while on alternate-day prednisolone (Fig. 1). There is limited data on relative efficacy of various steroid-sparing agents, and the choice of immunosuppressive strategy is guided by its efficacy, safety, cost and availability, patient age, disease severity, and parental preference (Table II). Potent medications are preferred in patients with high threshold $(>1 \mathrm{mg} / \mathrm{kg}$ on alternate day) relapses, relapses associated with lifethreatening complications, or with significant steroid toxicity (Box I and Table II). The presence of stable remission (up to one relapse in 6 months) during such therapy is acceptable, and except in severe steroid dependence, prednisolone is tapered and discontinued over few months. Therapy may be modified in patients with frequent relapses or significant adverse effects.

A proportion of patients with SSNS show disease characterized by multiple relapses despite therapy with steroid-sparing agents, and/or medication-associated toxicity. We propose defining difficult-to-treat nephrotic syndrome as patients with: (i) frequent relapses or infrequent relapses with significant steroid toxicity; and (ii) failure of 2 or more steroid sparing agents: levamisole, cyclophosphamide or MMF. These patients might merit therapy with agents such as CNI and rituximab. 
Frequently relapsing or steroid dependent nephrotic syndrome

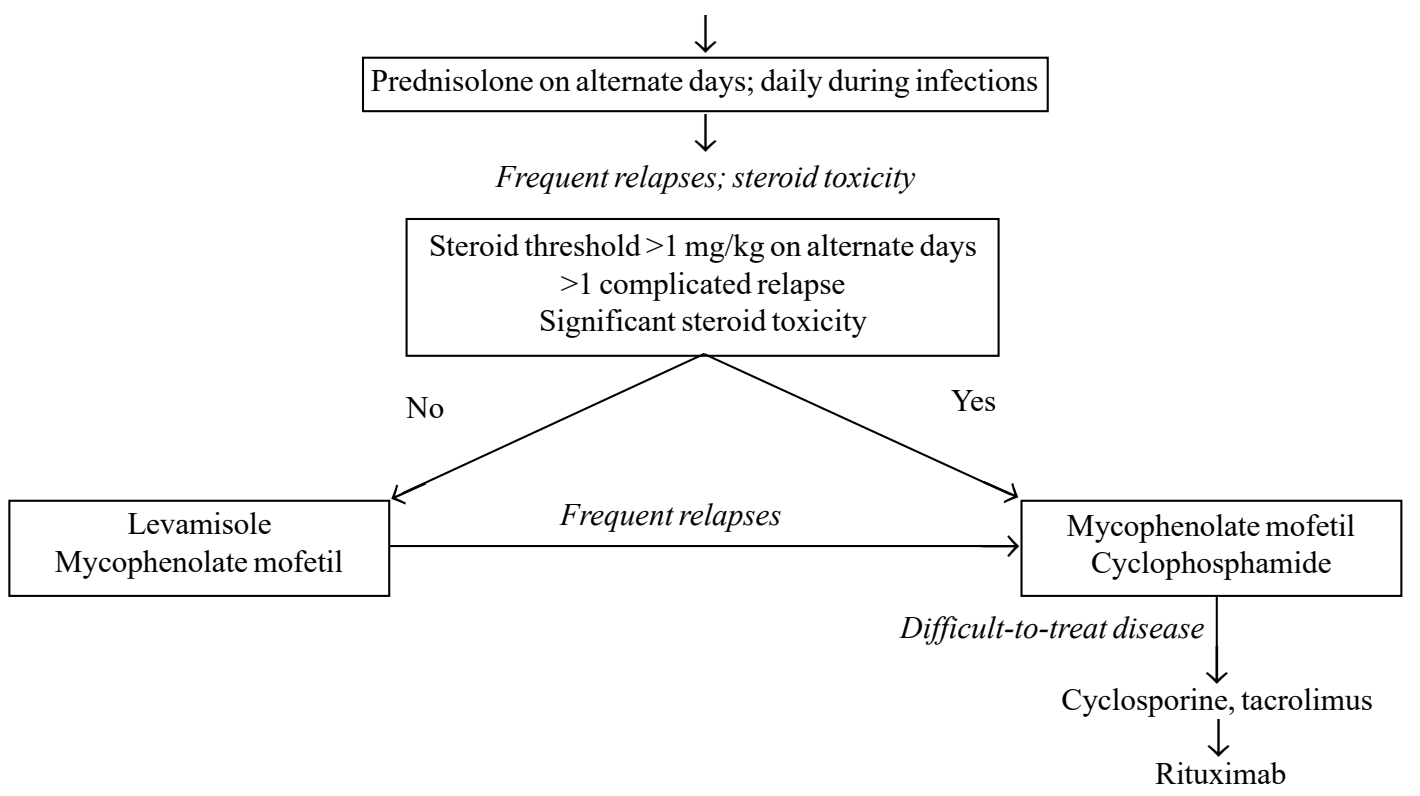

The initial strategy is to administer prednisolone at a dose of $0.5-0.7 \mathrm{mg} / \mathrm{kg}$ on alternate days. In patients with stable remission (sustained remission or infrequent relapses), therapy may be tapered to $0.2-0.3 \mathrm{mg} / \mathrm{kg}$ on alternate days for 6-12 months. Daily therapy at the same dose for 5-7 days, during minor infections, prevents infection-associated relapses. Patients who relapse at steroid threshold $>0.7 \mathrm{mg} / \mathrm{kg}$ or show steroid toxicity require therapy with steroid-sparing medications (Table II). The choice of agents is based on disease severity, adverse effects, patient age, cost of therapy, and parental preference. Levamisole or mycophenolate mofetil (MMF) are preferred medications for mild disease. Patients with high steroid threshold (>1 mg/kg on alternate days), complicated relapses and those with significant steroid toxicity (Box I) may be treated with MMF at higher doses (1000-1200 mg/m²/day) or cyclophosphamide. The use of cyclophosphamide is avoided in children $<5-7$ yr-old and in peri-pubertal boys due to reduced efficacy and risk of gonadal toxicity, respectively. Patients who relapse despite therapy with two or more steroid-sparing agents (difficultto treat steroid sensitive disease) are considered for therapy with calcineurin inhibitors, and failing that, rituximab. The use of rituximab is avoided in young children due to the risk of hypogammaglobulinemia.

Fig. 1. Management of frequently relapsing or steroid dependent nephrotic syndrome.

While the approach to management indicated in Fig. 1 suffices in most instances, individual situations may require different preference. Patients diagnosed either with steroid dependence soon after initial therapy, or with significant steroid toxicity at diagnosis of frequent relapses may be considered directly for steroid sparing therapies. Therapy with oral cyclophosphamide is avoided in young patients and in pubertal or post-pubertal boys. Therapy with CNI may be preferred to MMF in very young patients with significant steroid toxicity, even though the definition of difficult-to-treat SSNS is not met.

\subsection{Long-term corticosteroids}

- In patients with frequent relapses, we suggest tapering prednisolone to a dose of $0.5-0.7 \mathrm{mg} / \mathrm{kg}$ on alternate days, for 6-12 months.

- In patients receiving long term alternate-day prednisolone, we recommend administering the same dose daily for 5-7 days during fever or respiratory tract infection.

\section{Rationale}

Therapy with alternate-day prednisolone is the initial strategy for managing patients with frequent relapses [6,58]. Alternate-day prednisolone, often used as the control limb in RCTs, showed satisfactory response in 43-82.5\% patients (Supp. Table IV). A balance of benefit over harm is lacking, and there are risks of corticosteroid toxicity. Therefore, in patients in remission at prednisolone dose of $0.5-0.7 \mathrm{mg} / \mathrm{kg}$ for a few months, the medication may be tapered to $\sim 0.2-0.3 \mathrm{mg} / \mathrm{kg}$ on alternate days. The duration of therapy is at physician discretion, based on its efficacy and assessment of toxicity through monitoring of weight, height, blood pressure, ocular toxicity and hyperglycemia (Table II).

\section{Daily prednisolone during infections}

More than one-half of relapses in SSNS occur following upper respiratory tract infections. Evidence from three studies (Supp. Table V) indicates that, beginning with the onset of infection, switching therapy from alternate-day 
to daily administration of prednisolone for 5-7 days prevents the occurrence of relapses. One cross-over trial also supports the use of low-dose daily prednisolone in preventing infection-associated relapses in patients off corticosteroids [59]. Results of the PREDNOS2 trial will clarify the role of these strategies in preventing infectionassociated relapses (ISRCTN10900733).

\section{Daily prednisolone in low-dose}

Data from an open-label RCT [60] and a case series [61] suggests that low-dose $(0.2-0.3 \quad \mathrm{mg} / \mathrm{kg})$ daily prednisolone is associated with fewer relapses than twice the dose $(0.5-0.7 \mathrm{mg} / \mathrm{kg})$ on alternate days. The strategy led to lower steroid requirement and was not associated with toxicity [60]. These findings require confirmation in studies with longer follow-up that are powered to examine adverse effects, including suppression of the hypothalamo-pituitary-adrenal axis [62].

\subsection{Non-corticosteroid therapies}

- We recommend use of a steroid-sparing agent in patients failing therapy with alternate-day prednisolone, steroid toxicity or complicated relapses (Fig. 1).

- In patients failing alternate-day prednisolone, we recommend therapy with either levamisole or MMF for 12-24 months.

- We recommend MMF or cyclophosphamide in patients with significant steroid toxicity, high steroid threshold, complicated relapses, of failure of therapy with levamisole.

(1C)

Table II Immunosuppressive Medications for Frequent Relapses

\begin{tabular}{|c|c|c|c|c|}
\hline Medication & Dose & Duration & Adverse effects & Recommended monitoring \\
\hline Prednisolone & $\begin{array}{l}0.5-0.7 \mathrm{mg} / \mathrm{kg} \text { on } \\
\text { alternate days }\end{array}$ & $6-12 \mathrm{mo}$ & $\begin{array}{l}\text { Cushingoid features; short stature; } \\
\text { hypertension; raised intraocular } \\
\text { pressure; glucose intolerance; cata- } \\
\text { ract; elevated transaminases }\end{array}$ & $\begin{array}{l}\text { Screen for side effects, } \\
\text { Anthropometry q 3-6 } \\
\text { mo; eye evaluation q 6-12 } \\
\text { mo; blood sugar and } \\
\text { transaminases q 3-6 mo }\end{array}$ \\
\hline Levamisole & $\begin{array}{l}2-2.5 \mathrm{mg} / \mathrm{kg} \text { on } \\
\text { alternate days }\end{array}$ & $2-3$ years & $\begin{array}{l}\text { Leukopenia, ANCA positive vascu- } \\
\text { litis, high transaminases, seizures }\end{array}$ & $\begin{array}{l}\text { Blood counts }{ }^{c} \text { q 2-3 mo; } \\
\text { transaminases q 4-6 mo }\end{array}$ \\
\hline Cyclophosphamide & $\begin{array}{l}2-2.5 \mathrm{mg} / \mathrm{kg} / \text { day } \\
\text { orally }\end{array}$ & 8-12 weeks & $\begin{array}{l}\text { Leukopenia, alopecia, infections; } \\
\text { discolored nails; hemorrhagic cystitis; } \\
\text { gonadal toxicity and malignancies }\end{array}$ & $\begin{array}{l}\text { Blood counts q } 2 \text { weeks } \\
\text { Maintain hydration; } \\
\text { discontinue during significant } \\
\text { infections } \\
\text { Co-administer with } \\
\text { prednisolone } 1 \mathrm{mg} / \mathrm{kg} \mathrm{AD}\end{array}$ \\
\hline $\begin{array}{l}\text { Mycophenolate } \\
\text { mofetil }\end{array}$ & $\begin{array}{l}600-1200 \mathrm{mg} / \mathrm{m}^{2} / \mathrm{d} \\
\text { in divided doses; } \\
\text { AUC }>45 \mathrm{mg} \cdot \mathrm{h} / \mathrm{L}\end{array}$ & $2-3$ years & $\begin{array}{l}\text { Abdominal pain, diarrhea, nausea, } \\
\text { weight loss; viral warts; leukopenia; } \\
\text { elevated transaminases }\end{array}$ & $\begin{array}{l}\text { Screen for adverse effects } \\
\text { Blood counts }{ }^{c} \text { and trans- } \\
\text { aminases q 3-6 mo }\end{array}$ \\
\hline Cyclosporine & $\begin{array}{l}4-5 \mathrm{mg} / \mathrm{kg} / \mathrm{day} \text { in } \\
\text { divided doses; trough } \\
80-120 \mathrm{ng} / \mathrm{mL}^{a}\end{array}$ & $2-3$ years & $\begin{array}{l}\text { Both: Nephrotoxicity, hyperkalemia, } \\
\text { hepatotoxicity } \\
\text { Cyclosporine: Gingival hyperplasia, } \\
\text { hypertrichosis; hypertension; }\end{array}$ & $\begin{array}{l}\text { Screen for cosmetic side } \\
\text { effects, tremors, diarrhea, } \\
\text { hypertension } \\
\text { Creatinine, potassium }\end{array}$ \\
\hline Tacrolimus & $\begin{array}{l}0.1-0.2 \mathrm{mg} / \mathrm{kg} / \mathrm{d} \text { in } \\
\text { divided doses; trough } \\
4-8 \mathrm{ng} / \mathrm{mL}^{a}\end{array}$ & $2-3$ years & $\begin{array}{l}\text { dyslipidemia } \\
\text { Tacrolimus: Tremors, seizures, } \\
\text { headache; diarrhea; glucose } \\
\text { intolerance; hypomagnesemia }\end{array}$ & $\begin{array}{l}\text { at } 2-4 \text { weeks, q 3-6 mo } \\
\text { Liver function tests, } \\
\text { glucose, uric acid, magnesium } \\
\text { and lipids q 3-6 mo }\end{array}$ \\
\hline Rituximab & $\begin{array}{l}375 \mathrm{mg} / \mathrm{m}^{2} \text {, slow IV } \\
\text { infusion }\end{array}$ & $\begin{array}{l}2 \text { doses, } \\
1 \text {-week } \\
\text { apart }^{d}\end{array}$ & $\begin{array}{l}\text { Chills, fever; serum sickness; } \\
\text { bronchospasm } \\
\text { Acute lung injury } \\
\text { Neutropenia; } P \text {. jirovecii pneumonia; } \\
\text { reactivation of hepatitis B or JC virus; } \\
\text { hypogammaglobulinemia }\end{array}$ & $\begin{array}{l}\text { Pre dose: Blood counts, } \\
\text { transaminases; hepatitis and } \\
\text { HIV serology; immuno- } \\
\text { globulin G (IgG) level } \\
\text { Post therapy: CD19 counts; } \\
\text { blood counts and IgG }\end{array}$ \\
\hline
\end{tabular}

$A U C$ area under the curve (therapeutic drug monitoring); mo months; ${ }^{a}$ May reduce dose further if remission is sustained; ${ }^{b}$ During infections, administer alternate day prednisolone at $0.5 \mathrm{mg} / \mathrm{kg}$ every day for $5-7 \mathrm{~d}$ to prevent relapse; ${ }^{c}$ Withhold if total leukocyte count $<4000 / \mathrm{mm}^{3 ;}{ }^{3}$ One to two additional doses are given at weekly intervals if CD19+ cells are $>5 / \mu L$ (or $>1 \%$ of CD $45+$ cells) despite two doses of rituximab. 


\section{Rationale}

Levamisole: Levamisole has been used for almost 4decades, mainly in Asia and Europe, as a steroid-sparing agent for frequent relapsing nephrotic syndrome [63]. A meta-analysis (8 studies, 462 patients; Supp. Table VI), suggests $35 \%$ reduction in the risk of relapses following 6-12 months' therapy with levamisole (RR 0.65; 95\% CI $0.48-0.88$ ) [64]. The medication is more useful in patients with frequent relapses than in steroid dependence [65]. Comparative studies indicate that the risk of relapse in patients receiving levamisole is similar to cyclophosphamide (2 studies, 97 children; RR 2.14; 95\% CI 0.22-20.95), or MMF (one study, 149 patients; RR $1.11 ; 95 \%$ CI 0.86-1.43) [64]. Given the efficacy and safety, the agent is being examined in two RCTs when administered at onset of the disease (LEARNS, EudraCT 2017-001025-41; NEPHROVIR3, NCT02818738).

Levamisole is given at the dose of $2-2.5 \mathrm{mg} / \mathrm{kg}$ on alternate days (Table II). While few retrospective studies report its efficacy when administered daily (Supp. Table VII), the safety of this strategy should be examined in controlled studies with close monitoring for adverse effects, including neutropenia, raised transaminases, antineutrophil cytoplasmic antibodies and/or small vessel vasculitis $[63,66,67]$.

Mycophenolate mofetil (MMF): The use of MMF in frequently relapsing nephrotic syndrome is recent [68]. A review of 7 prospective and 6 retrospective series (508 patients) showed that therapy with MMF for 6-19 months lowered relapse rates, and reduced requirement of prednisolone and/or CNI (Supp. Table VIII) [68]. While placebo-controlled, blinded RCTs are lacking, MMF was found to be comparable to levamisole but inferior to cyclosporine in maintaining satisfactory remission or reducing the frequency of relapses in 3 open-label RCTs (Supp. Table IX) [64]. Likewise, MMF had efficacy similar or inferior to tacrolimus in a non-randomized comparison (Supp. Table IX). MMF is perhaps more efficacious in young children [69], and more effective than levamisole in patients with steroid dependence [70].

Therapy with MMF is given in two divided doses, 600 to $1200 \mathrm{mg} / \mathrm{m}^{2}(20-30 \mathrm{mg} / \mathrm{kg})$ daily [68]. Doserelated adverse effects include leukopenia, abdominal pain and diarrhea. Data from one RCT suggests that patients with higher blood levels of MMF (determined by area under the curve, AUC) show efficacy similar to cyclosporine [71]. Others emphasize the need to achieve mycophenolic acid AUC levels exceeding 45-60 $\mu \mathrm{g} * \mathrm{~h} /$ $\mathrm{mL}$ [72-74] or trough levels $>2-3 \mu \mathrm{g} / \mathrm{mL}$ [75-78]. While pharmacokinetics of MMF is variable, adequate levels are achieved with high doses [76-78]. In the absence of facilities for therapeutic drug monitoring, we propose initiating therapy at the lower end of dose range and escalating as tolerated, to $1000-1200 \mathrm{mg} / \mathrm{m}^{2}$, if the patient continues to relapse.

Cyclophosphamide: Oral cyclophosphamide, at 2-2.5 mg/ $\mathrm{kg}$ daily for 8-12 weeks, is the most commonly used steroid-sparing agent in SSNS. Its use finds basis in evidence of efficacy and overall safety, as summarized in a systematic review (38 prospective and retrospective studies, 1504 patients) of patients administered cyclophosphamide or chlorambucil [79]. A recent meta-analysis shows reduced risk of relapse at 6-12 months (6 studies, 202 patients; RR 0.44; 95\% CI 0.32-0.60) and 12-24 months (4 studies, 59 patients; RR 0.20; 95\% CI 0.09-0.46) following therapy with alkylating agents [64]. In comparative studies, the risk of relapse at 12-24 months following cyclophosphamide therapy was similar to levamisole (1 study, 40 patients; RR 1.12; 95\% CI 0.861.16), but lower than cyclosporine ( 2 studies, 95 patients; RR 0.51; 95\% CI 0.35-0.74) [64]. A Bayesian network analysis (7 reports, 391 patients) showed lowest relapse rates with cyclophosphamide, compared to other medications [80]. Cyclophosphamide is more effective in patients with frequent relapses than in steroid dependence, and in patients older than 5-7 years (Supp. Table X).

Therapy with cyclophosphamide is initiated during remission. Prednisolone is given at a dose of $\sim 1 \mathrm{mg} / \mathrm{kg}$ on alternate days during therapy with cyclophosphamide; the medication may subsequently be stopped after 1-2 months. Leukopenia is the chief adverse effect, reported in one-third of patients; other concerns are alopecia and the risk of infections (Table II). Leukocyte count is monitored every 2 weeks, and therapy withheld if the count falls below $4000 / \mathrm{mm}^{3}$. Increased fluid intake and frequent voiding prevents hemorrhagic cystitis which, along with nausea and vomiting, is common with intravenous (IV) dosing. The risk of gonadal toxicity is proportionate to the cumulative dose, and appears to be high in pubertal and post-pubertal boys (Tanner stage 2 or more), and lower in girls [30,79,81]. Therapy with chlorambucil is associated with risk of seizures, and is not recommended.

Given concerns of gonadal toxicity and malignancy, therapy with cyclophosphamide is usually administered after failure of levamisole or MMF, and is limited to one 12 -weeks' course (cumulative $\sim 168 \mathrm{mg} / \mathrm{kg}$ ). Occasionally, cyclophosphamide may be the preferred initial steroidsparing therapy in patients older than 7-yr, particularly in presence of significant steroid toxicity and/or complicated relapses. Limited evidence indicates that cyclophosphamide $\left(500 \mathrm{mg} / \mathrm{m}^{2}\right.$ monthly IV pulse; 
6-doses) is as effective as 12-weeks' oral therapy [64], and may be considered in patients with likely non-compliance to oral therapy.

\subsection{Difficult-to-treat steroid sensitive nephrotic syndrome}

- We recommend therapy with CNI, either cyclosporine or tacrolimus, in patients with difficult-to-treat SSNS.

- We recommend therapy with rituximab in patients who have either failed CNI or have received these agents for a prolonged duration.

- We suggest that therapy with rituximab be administered during disease remission after ruling out acute and chronic infections, and should target B cell depletion.

\section{Rationale}

Calcineurin inhibitors: Observational studies indicate that CNI (cyclosporine 4-6 mg/kg/day, tacrolimus 0.1-0.2 mg/ $\mathrm{kg} /$ day, in two divided doses) maintain remission and enable steroid-sparing in $60-90 \%$ patients with frequent relapses or steroid dependence who have failed treatment with alkylating agents [82-84]. These agents have not been compared to placebo or to each other in controlled studies for SSNS. While one RCT each found that cyclosporine was associated with reduced risk of relapse as compared to prednisolone (104 children; RR $0.33 ; 95 \%$ CI $0.13-0.83$ ) or MMF (see above), patients relapsed when the therapy was discontinued [64]. In view of the efficacy and significant steroid-sparing, CNI are preferred for patients with high threshold relapses or significant corticosteroid toxicity. While therapy with CNI is usually restricted to patients with difficult-to-treat SSNS (Box I), these agents may be considered before MMF or cyclophosphamide in young children with severe steroid dependence and/or significant steroid toxicity. The choice of the medication should follow discussion with parents about potential toxicities and the need for monitoring.

Chief adverse effects of CNI include acute and chronic nephrotoxicity (with both agents), hirsutism, gum hypertrophy, hypertension and hyperlipidemia (with cyclosporine), and hyperglycemia or seizures (with tacrolimus) $[82,83]$. While tacrolimus is preferred to cyclosporine due to lack of cosmetic effects, only the latter is available as an oral suspension for young children. Therapy should be administered for at least 12-months, with monitoring of drug levels (Table II). Lower target trough levels and once-daily dosing is acceptable during sustained remission [85.86]. The role of protocol biopsies, before initiating therapy with $\mathrm{CNI}$ and following their prolonged use, is discussed in Guideline 2.
Rituximab: B cell depletion has emerged as an effective strategy for sustaining remission in patients with steroidand/or CNI-dependent nephrotic syndrome. Therapy with rituximab (375 mg/m $/ \mathrm{m}^{2}$ IV once a week for 1-4 doses) in 13 prospective and retrospective series $(n=159)$ led to sustained remission in $25-71 \%$ patients, postponement of relapse by (median) 5-11 months, and withdrawal of other therapies [87]. A systematic review confirmed similar efficacy in 86 adults administered rituximab for frequent relapses [88]. In non-randomized comparisons, the efficacy of rituximab was superior to cyclophosphamide (2 studies, 148 patients) and comparable to tacrolimus (1 study, 23 patients) (Supp. Table XI). In a prospective study, therapy with 2-3 doses of rituximab in 101 patients was associated with over two-third reduction in relapses, postponement of relapse by median 16-months and reduced steroid requirement [89].

Data from 7 RCTs in patients with frequent relapses and steroid/CNI dependence indicates superior efficacy of rituximab as compared to placebo ( 2 studies, 71 patients), or no additional therapy ( 2 studies, 91 patients); the efficacy was similar or superior to CNI in one study each (174 patients) (Supp. Table XI). A Cochrane metaanalysis concluded that therapy with rituximab, in combination with CNI and prednisolone, versus the latter alone, reduced the risk of relapse at 6 months ( 5 studies, 269 patients; RR $0.23,95 \%$ CI $0.12-0.43$ ) and 12 months (3 studies, 198 patients; RR 0.63, 95\% CI 0.42-0.93) [64].

Experts advise administering rituximab at a dose of $375 \mathrm{mg} / \mathrm{m}^{2} \mathrm{IV}$, using B cell depletion (CD19+ cells $<1 \%$ of CD $45+$ cells, or $<5$ cells $/ \mu \mathrm{L}$ ) as a marker for adequacy of dosing. While B cell depletion is usual after even one dose [87], a maximum of 4 infusions have been given. Since administration of rituximab during relapse is associated with its urinary excretion and reduced halflife, therapy is preferred during remission [90]. B cell recovery usually occurs by 6-9 months, and is associated with risk of relapses $[87,88,90]$. Studies comparing response to rituximab in relation to the number of doses and use of maintenance immunosuppression are summarized in Supp. Table XII. An international cohort on 511 patients with frequent relapses or steroid dependence showed that relapse-free survival was significantly shorter for patients given a single dose of rituximab (8.5 months) compared to those given two (12.7 months) or more doses (14.3 months) [91]. Additional immunosuppression was useful in sustaining remission following therapy with a single dose of rituximab. In patients with difficult-to-treat SSNS with satisfactory response to rituximab, repeated doses of the medication, following relapses or repopulation of $\mathrm{B}$ cells, is suggested as a strategy to sustain remission 
(Supp. Table XII). Given the concerns discussed below, the optimal strategy is still not clear.

Systematic reviews show that therapy with rituximab is associated with infusion reactions (4 studies, 252 children; RR 5.8, 95\% CI 1.3-25.3) [64], delayed adverse events and infections $[87,88]$. A German registry of autoimmune diseases (370 patients) reported serious infections in 5.3 cases per 100 patient-years [92]. Patients with lymphoma treated with rituximab show reactivation of hepatitis B virus infection in 9\% (95\% CI 5\%-15\%) patients [93]. In contrast to the reports of normal $\mathrm{IgG}$ in adult patients receiving multiple doses of rituximab (Supp. Table XII), hypogammaglobulinemia is not uncommon in children with nephrotic syndrome and autoimmune diseases. The risk of hypogammaglobulinemia correlates inversely with age, and positively with the number of rituximab doses [94-96].

We recommend that rituximab be used in patients with difficult-to-treat disease, under the supervision of a pediatric nephrologist. Its use should be avoided in young children ( $<5-7 \mathrm{yr}$ old), and restricted to patients failing other steroid-sparing agents. Active acute infections and chronic viral infections should be ruled out before therapy. We recommend administering two doses of rituximab during disease remission, at $375 \mathrm{mg} / \mathrm{m}^{2}$ oneweek apart, followed by confirmation of B cell depletion, 2-7 days after the second dose. Vigilance for infections and monitoring for leukopenia and hypogammaglobulinemia is essential during follow up. Further doses of rituximab should be avoided in patients with severe infusion-related adverse events, severe infections or with hypogammaglobulinemia. Prophylactic antibiotics are not routinely recommended. We suggest administering cotrimoxazole $\left(150 \mathrm{mg} / \mathrm{m}^{2}\right.$ or $5 \mathrm{mg} / \mathrm{kg}$ of trimethoprim on alternate days) in patients receiving additional immunosuppression, such as those receiving maintenance treatment with CNI or MMF following therapy with rituximab.

\section{SUPPORTIVE CARE}

Patients with nephrotic syndrome are at risk of complications of the disease, and side effects of its medications. Principles of management of hypertension, thromboembolism, growth retardation, obesity, dyslipidemia, and hypothyroidism are discussed in the guidelines on steroid resistant nephrotic syndrome [10]. We emphasize that patients who have received oral steroids for more than 2-weeks within the past one-year, should receive additional corticosteroids during conditions associated with physiological stress like systemic infections, inadequate oral intake, lethargy, dehydration, invasive or dental surgery, trauma and large burns [10]. Conditions such as uncomplicated viral infections, acute otitis media and fever following immunization do not require stress dosing with steroids.

\section{Guideline 6: Management of Hypovolemia and Edema}

Edema, a cardinal feature of nephrotic syndrome, often requires specific therapy. We propose that edema be empirically classified based on appearance and percentage weight gain from baseline, as mild $(\leq 7 \%$ increase), moderate ( $8-15 \%$ ) and severe ( $>15 \%$ increase) [97]. If urine protein is monitored regularly, the occurrence of more than mild edema is unusual. Patients with severe edema have marked hypoalbuminemia (serum albumin $<1.5 \mathrm{~g} / \mathrm{dL}$ ), along with ascites and anasarca that interferes with daily activities [97,98]. Intravascular volume depletion is common in patients with moderate or severe edema $[99,100]$, and should be assessed before instituting therapy with diuretics.

\subsection{Hypovolemia}

- We recommend that patients with moderate to severe edema be assessed for intravascular volume status before initiating therapy with diuretics (Fig. 2). (X)

- We recommend the use of normal saline and IV albumin in patients with disease relapse and hypovolemia.

\section{Rationale}

A combination of clinical and biochemical features helps estimate intravascular volume (Box III, Fig. 2) [97,101]. Patients with hypovolemia often have abdominal pain, nausea, vomiting, dizziness and lethargy. Examination shows tachycardia, pallor, cold peripheries, delayed

\footnotetext{
Box III Features of Hypovolemia During Relapse

Clinical features

Abdominal pain, vomiting, lethargy

Prolonged capillary refill time; cold extremities

Tachycardia, low volume pulses

Low blood pressure; postural hypotension

Biochemical indices

Elevated hematocrit

Blood urea $(\mathrm{mg} / \mathrm{dL})$ to creatinine $(\mathrm{mg} / \mathrm{dL})$ ratio $>100$

Fractional excretion of sodium $<0.5 \%$

Urinary potassium index [urine $\mathrm{K}^{+} /\left(\right.$urine $\left.\mathrm{Na}^{+}+\mathrm{K}^{+}\right)>0.6$ ]

Ultrasonography: decreased inferior vena cava diameter, increased collapsibility index [110]

Fractional excretion of sodium $=\frac{\text { urine } \mathrm{Na}^{+} \times \text {serum creatinine } \times 100}{\text { serum } \mathrm{Na}^{+} \times \text {urine creatinine }}$
} 


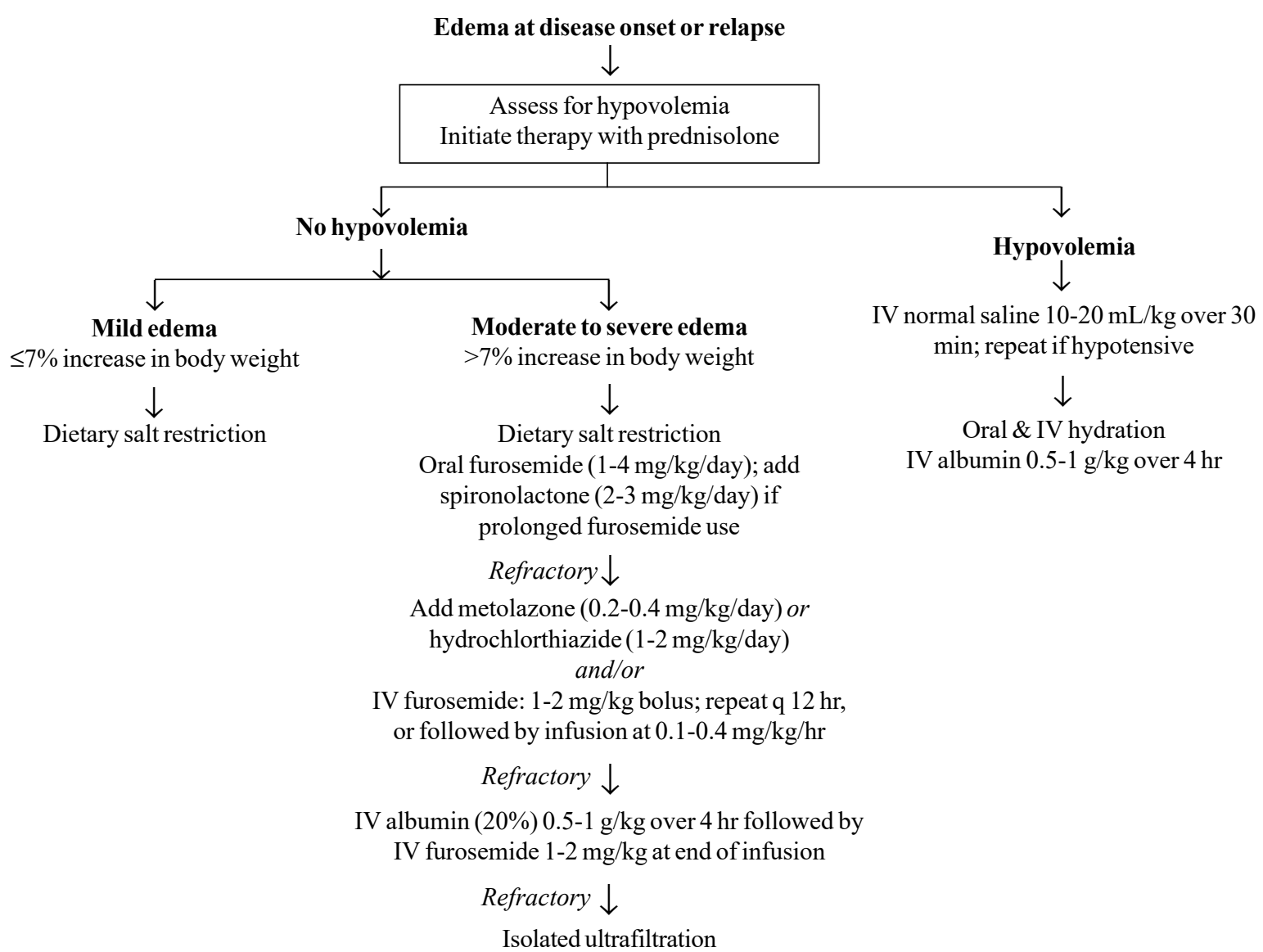

Edema is empirically defined, based on increase in body weight, as mild, moderate and severe (>15\% increase). Patients with mild edema are managed with salt restriction alone; prednisolone therapy is associated with spontaneous diuresis within a few days. Hypovolemia should be excluded (Box III) before considering therapy with diuretics. Oral furosemide is the diuretic of choice; patients receiving therapy with furosemide for $>48$-hr should additionally receive a potassium-sparing diuretic. Edema refractory to furosemide therapy may be treated with additional thiazide diuretics or IV furosemide, as bolus and/or infusion. Combination therapy with IV albumin (20\%) and furosemide enables diuresis in patients refractory to the above measures. IV albumin carries the risk of fluid overload and pulmonary edema in patients with renal dysfunction. Patients with features of hypovolemia require bolus(es) of normal saline if hypotensive, followed by oral and IV hydration, and IV albumin (20\%) infused over 2-4 hr.

Fig. 2. Management of edema in nephrotic syndrome.

capillary refill and postural hypotension, and rarely shock $[97,101,102]$. On the other hand, patients with hypervolemia have refractory anasarca, hypertension and dyspnea [99,100]. Two urinary indices may help assess intravascular volume: fractional excretion of sodium (FENa) and potassium index [103,104]. While both underfill and overfill states are associated with sodium retention [105-107], FENa $<0.5 \%$ and potassium index $>0.6$ indicate high aldosterone activity, characteristic of hypovolemia [104,105,108]. The indices are not reliable with recent diuretic therapy and while receiving IV fluids. Other parameters of volume status include changes in hematocrit, urea to creatinine ratio [105], inferior vena cava diameter and collapsibility, and bioimpedance analysis [97,99-101,109,110].
Hypovolemia may occur at disease onset or relapse, particularly in a setting of diarrhea, vomiting or unsupervised diuretic therapy. Therapy with diuretics should be discontinued. Hypotensive patients should receive 1-2 boluses of isotonic saline $(10-20 \mathrm{ml} / \mathrm{kg}$ infused over 20-30 minutes) and/or 5\% albumin (10-15 $\mathrm{ml} / \mathrm{kg}$ over 30-60 minutes) (Fig. 2). Subsequently, patients are managed with IV and oral hydration, and IV albumin (20\%; 0.5-1 g/kg over 3-4 hr) [97,99,101].

\subsection{Edema}

- We recommend oral furosemide as first line therapy for patients with moderate edema without hypovolemia (Fig. 2).

(1C)

- We suggest that patients with furosemide-refractory 
edema be managed as follows: (i) combination of loop diuretics with thiazide; (ii) co-administration of human albumin with IV furosemide.

\section{Rationale}

Patients with mild edema do not require diuretic therapy. Corticosteroid therapy for relapse results in diuresis within one-week, enabling loss of retained extracellular fluid $[97,101]$. Patients are advised to limit sodium intake $(1-2 \mathrm{mEq} / \mathrm{kg} / \mathrm{day} ; 15-35 \mathrm{mg} / \mathrm{kg}$ salt $)$. Foods rich in salt (>10 mEq/100 g; e.g., bread, cornflakes, processed cheese, sauces, potato chips, salted nuts, papad, pickles) and preserved foods (canned vegetables, soups and meat) are avoided in presence of significant edema [97,101].

Diuretics are the initial therapy for patients who are volume replete. Patients with moderate edema without hypovolemia are managed with furosemide $(2-4 \mathrm{mg} / \mathrm{kg} /$ day) that acts on the ascending limb of Henle $[101,105]$. Sequential nephron blockade, with additional use of hydrochlorothiazide (2-4 mg/kg/day) or metolazone ( 0.1 $0.2 \mathrm{mg} / \mathrm{kg} \mathrm{q} 12-24 \mathrm{hr}$ ), augments diuresis by reducing distal sodium reabsorption [97,101]. Monitoring for hypovolemia, hypokalemia and alkalosis is essential. Spironolactone has limited diuretic efficacy, but is an effective potassium-sparing agent in patients receiving high-dose furosemide [97,101]. Use of acetazolamide or amiloride is not advised.

Patients with severe edema may fail to respond to maximal doses of furosemide and thiazide diuretics (diuretic resistance) [98]. Factors contributing to diuretic resistance are poor adherence to salt restriction, reduced bioavailability of furosemide, hypoalbuminemia, hypovolemia, and compensatory salt reabsorption in the distal tubule. The bioavailability of oral furosemide is 20 $60 \%$, and is impaired by gut edema in nephrotic syndrome [98]. In patients unresponsive to oral furosemide, assessed as absence of diuresis within 2-4 hr of its administration, switching to IV therapy may elicit a response. IV furosemide, given either as $1-2 \mathrm{mg} / \mathrm{kg} \mathrm{q} \mathrm{8-}$ $12 \mathrm{hr}$, or bolus of $1 \mathrm{mg} / \mathrm{kg}$ followed by infusion of $0.1-0.4$ $\mathrm{mg} / \mathrm{kg} / \mathrm{hr}$ is effective $[97,98,101]$. While torsemide has better efficacy and bioavailability than furosemide in adults with heart failure [111], information in nephrotic syndrome is lacking.

Furosemide, tightly bound to blood albumin, is actively secreted via organic acid pumps in the ascending limb of Henle. Tubular secretion is impaired in patients with severe hypoalbuminemia, resulting in diuretic resistance [101]. The combination of $20 \%$ albumin $(0.5-1$ $\mathrm{g} / \mathrm{kg}$ infused over 3-4 hr) and furosemide (1-2 $\mathrm{mg} / \mathrm{kg}$ at end of infusion) enhances drug delivery to tubules, with increased efficacy in terms of urine output and weight loss $[110,112,113]$. A meta-analysis confirmed that combination therapy results in diuresis and natriuresis, which declines by $24-\mathrm{hr}[101,114]$. Therapy with IV albumin may be associated with risk of worsening hypertension, respiratory distress and heart failure, and is therefore avoided in patients with impaired kidney function $[97-99,101,112]$.

Patients with severe edema who are refractory to the above therapies are likely to have fluid overload, usually in presence of steroid resistance or kidney dysfunction. These patients might require ultrafiltration or kidney replacement therapy. An approach to evaluation and management of edema is shown in Fig. 2.

\section{Guideline 7: Infections and Immunization}

\subsection{Bacterial infections}

We suggest that serious bacterial infections associated with nephrotic syndrome be managed as indicated in Table III.

\section{Rationale}

Infections are the chief complication in patients with SSNS, accounting for $19-44 \%$ of hospitalizations [115-120]. Contributing factors include the use of immunosuppressive agents, anasarca, and urinary losses of IgG and complement factors, that predispose to infection with encapsulated organisms [121]. Peritonitis is the most common severe infection, followed by pneumonia and cellulitis [115-119]. Chief pathogens causing peritonitis are pneumococci and E. coli; those causing pneumonia include pneumococci, $H$. influenzae and $S$. aureus; and those responsible for cellulitis are staphylococci, group A streptococci and $H$. influenzae [115-119]. The diagnosis and treatment of severe infections should follow standard guidelines [122124] (Table III). Apart from vaccines, there is no evidence of efficacy of other interventions for preventing bacterial infections in patients with nephrotic syndrome [125].

\section{Viral infections}

Several viruses, including rhinovirus, adenovirus, influenza, parainfluenza, enterovirus, and respiratory syncytial and Epstein Barr viruses, might trigger disease relapses $[126,127]$. Infections such as varicella, zoster and influenza might be associated with significant morbidity, and merit specific prevention and management [128-130].

Severe acute respiratory syndrome coronavirus-2 (SARS-CoV-2) infection: Infection with SARS-CoV2, the etiological agent of coronavirus disease (COVID-19), poses challenges in management of patients with nephrotic syndrome [131]. While children show mild 
Table III Management of Serious Infections

\begin{tabular}{|c|c|c|c|}
\hline Infections & Organisms & Diagnosis & Treatment \\
\hline Peritonitis & $\begin{array}{l}\text { S. pneumoniae, } \\
\text { S. pyogenes } \\
\text { E. coli, Gram } \\
\text { negative bacteria }\end{array}$ & $\begin{array}{l}\text { Ascitic fluid: }>100 \text { white cells } / \mathrm{mm}^{3} \text {, } \\
>50 \% \text { neutrophils } \\
\text { Ascitic fluid: Culture, latex } \\
\text { agglutination, PCR }\end{array}$ & $\begin{array}{l}\text { Ceftriaxone or cefotaxime for } 7-10 \mathrm{~d} \\
\text { Ampicillin and gentamicin/amikacin for } 7-10 \mathrm{~d}^{a}\end{array}$ \\
\hline Pneumonia & $\begin{array}{l}\text { S. pneumoniae, } \\
\text { S. aureus, } \\
\text { H. influenzae } \\
\text { Influenza H1N1 } \\
\text { M. tuberculosis }\end{array}$ & $\begin{array}{l}\text { Chest X ray; blood culture; } \\
\text { sputum for Gram stain and culture } \\
\text { Throat swab for H1N1 by PCR } \\
\text { Tuberculin test; pleural tap, gastric } \\
\text { aspirate, sputum: acid fast bacilli, } \\
\text { CBNAAT }\end{array}$ & $\begin{array}{l}\text { Oral: Amoxicillin, coamoxiclav, cefuroxime for } \\
10-14 \mathrm{~d}^{a} \\
\text { Parenteral: Ceftriaxone; or ampicillin and amikacin for } 7-10 \mathrm{~d}^{a} \\
\text { Oseltamivir for } 5 \mathrm{~d} \\
\text { Therapy as per National Tuberculosis Elimination } \\
\text { Program [16] }\end{array}$ \\
\hline Cellulitis & $\begin{array}{l}\text { S. aureus, } \\
\text { S. pyogenes } \\
\text { H. influenzae } \\
\text { Gram negative } \\
\text { bacteria }\end{array}$ & $\begin{array}{l}\text { Pus for culture, sensitivity } \\
\text { Blood culture }\end{array}$ & $\begin{array}{l}\text { Parenteral: Coamoxiclav; cloxacillin with } \\
\text { ceftriaxone for } 7-10 \mathrm{~d}^{a}\end{array}$ \\
\hline Sepsis & $\begin{array}{l}\text { S. pneumoniae, } \\
\text { Gram negative } \\
\text { bacteria }\end{array}$ & $\begin{array}{l}\text { Complete blood counts; } \\
\text { C-reactive protein, procalcitonin; } \\
\text { blood culture }\end{array}$ & Ceftriaxone and amikacin for $10-14 \mathrm{~d}^{a}$ \\
\hline Varicella & $\begin{array}{l}\text { Varicella zoster } \\
\text { virus }\end{array}$ & Clinical & $\begin{array}{l}\text { IV acyclovir }\left(1500 \mathrm{mg} / \mathrm{m}^{2} / \text { day in three doses }\right) \\
\text { or oral acyclovir }(80 \mathrm{mg} / \mathrm{kg} / \text { day in four doses }) \text { for } 7-10 \mathrm{~d}\end{array}$ \\
\hline
\end{tabular}

CBNAAT-cartridge based nucleic acid amplification test; PCR-polymerase chain; ${ }^{a}$ Penicillin allergy: Clarithromycin, azithromycin, clindamycin or vancomycin.

disease, patients on immunosuppression constitute a high-risk group that is predisposed to adverse outcomes. Affected patients are at risk of AKI, particularly if associated with hypovolemia or aggressive use of diuretics. In absence of specific therapy for SARS-CoV-2 infection, most expert groups advise reduction of immunosuppression to acceptable levels, balancing the risk of disease relapses against infection [131,132]. Other considerations include advice through teleconsultation; low threshold for inpatient monitoring of infected patients; and limiting the use of biological agents and antimetabolites $[131,132]$. Steroid dosing during SARSCoV-2 infection should follow standard practices regarding stress dosing [10]; relapses may be treated with a lower dose of prednisolone.

\subsection{Immunization}

We suggest that patients with nephrotic syndrome receive: (i) age-appropriate killed, subunit or inactivated vaccines; (ii) live vaccines following principles outlined in Table IV; (iii) vaccines against pneumococcus, varicella, influenza and hepatitis B (Table V).

\section{Rationale}

Children with nephrotic syndrome should receive vaccines as appropriate for age $[133,134]$. Killed, inactivated or subunit vaccines are not contraindicated, but may have reduced efficacy during immunosuppression [133-136]. Principles of immunization with live vaccines in immunocompromised children and their household contacts are listed in Table IV [124,134,137]. The schedule for administration of specific vaccines that are relevant to patients with nephrotic syndrome is summarized in Table V $[133,134,138]$. The risk of relapse following vaccination is negligible $[135,139]$.

\section{Pneumococcal Vaccine}

The availability of safe and immunogenic vaccines has reduced the risk of pneumococcal infections in patients with relapsing nephrotic syndrome [140]. Two categories of vaccines are available. The polysaccharide vaccine (PPSV23) is poorly immunogenic in patients younger than 2-years, and does not induce immunological memory. Conjugate vaccines (PCV7-, 10- and 13-valent) induce superior and sustained antibody responses and immune memory even in young infants, with pooled efficacy of 58\% (95\% CI 29-75\%) against invasive disease caused by any pneumococcal serotype [135,141]. The efficacy of PPSV23 and PCV vaccines in patients with SSNS is variable. Information is lacking on the precise impact of vaccination on rates of peritonitis, cellulitis and pneumonia. 
Table IV Principles of Immunization with Live Vaccines in Patients with Nephrotic Syndrome

\begin{tabular}{|c|c|}
\hline Immunosuppression & Advice \\
\hline $\begin{array}{l}\text { Receiving high dose prednisolone }(\geq 2 \mathrm{mg} / \mathrm{kg} / \mathrm{d} ; \geq 20 \mathrm{mg} / \text { day } \\
\text { if }>10 \mathrm{~kg} \text { ) for }<14 \mathrm{~d}\end{array}$ & Vaccinate immediately after discontinuing treatment \\
\hline $\begin{array}{l}\text { Receiving high dose prednisolone }(\geq 2 \mathrm{mg} / \mathrm{kg} / \mathrm{d} ; \geq 20 \mathrm{mg} / \text { day } \\
\text { if }>10 \mathrm{~kg} \text { ) for } \geq 14 \mathrm{~d}\end{array}$ & Vaccinate 1-month after discontinuing corticosteroids \\
\hline $\begin{array}{l}\text { Receiving low-moderate dose prednisolone }(<2 \mathrm{mg} / \mathrm{kg} / \mathrm{d} \text { or } \\
\text { equivalent }<<20 \mathrm{mg} / \mathrm{d})\end{array}$ & No live vaccines until discontinuation of steroid therapy \\
\hline Low-dose alternate day prednisolone and pressing need for vaccine & Live vaccine may be administered \\
\hline Patients receiving cyclophosphamide & Avoid live vaccines until off therapy for 3 months \\
\hline $\begin{array}{l}\text { Patients receiving calcineurin inhibitors, levamisole or } \\
\text { mycophenolate mofetil }\end{array}$ & Avoid live vaccines until off therapy for 1 month \\
\hline Therapy with rituximab & Avoid live vaccines until after B-cell recovery ( $\sim 6-9$ months) \\
\hline Immunocompetent siblings and household contacts & $\begin{array}{l}\text { Do not administer oral polio vaccine; may receive measles- } \\
\text { mumps-rubella, rotavirus and varicella vaccines }\end{array}$ \\
\hline Household contacts older than one year & Administer influenza vaccine annually \\
\hline
\end{tabular}

Table V Specific Vaccines for Patients with Nephrotic Syndrome ${ }^{a}$

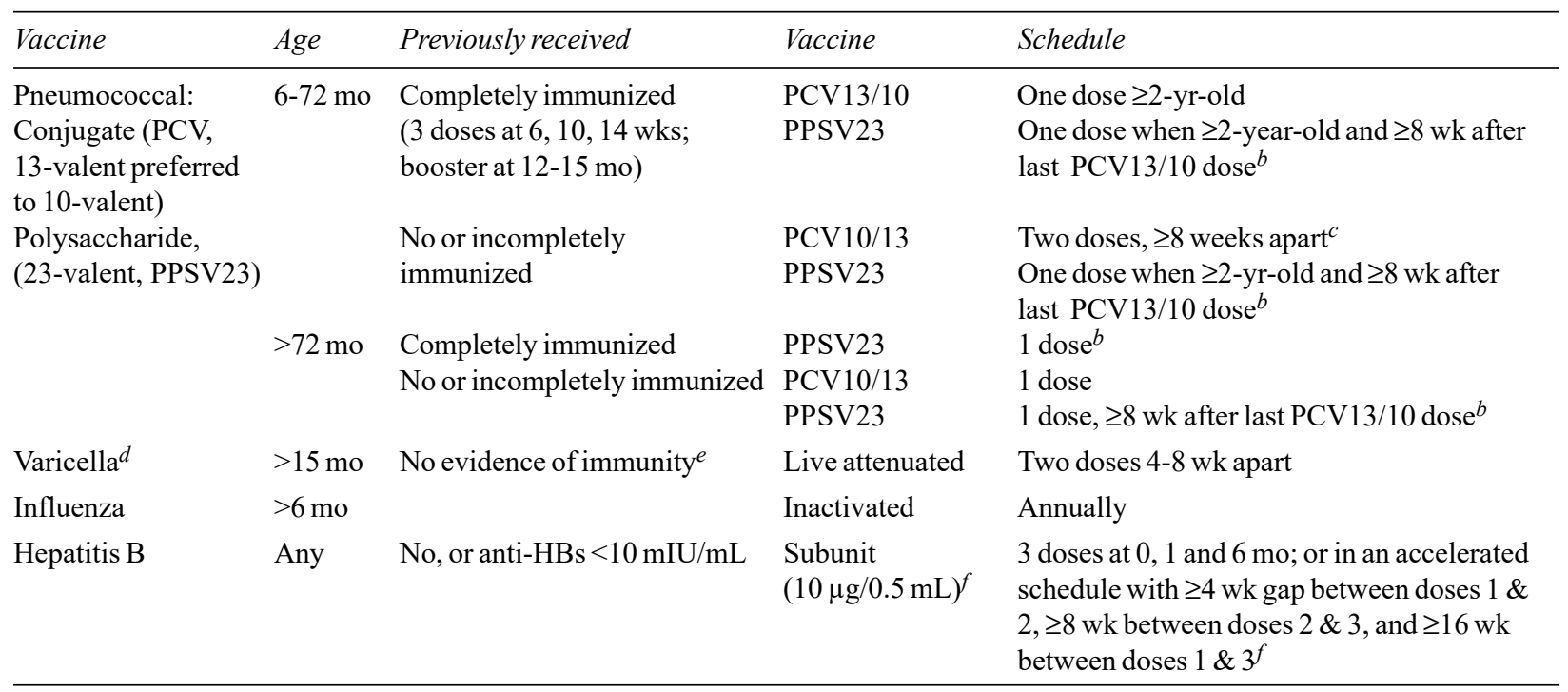

${ }^{a}$ Efficacy of vaccines might be attenuated while on high dose corticosteroids or other immunosuppression; ${ }^{b}$ Repeat after 5-yr if still experiencing disease relapses; ${ }^{c}$ If the two doses are administered at $<1$-yr-old, give one additional dose during second year of life; ${ }^{d}$ Avoid in patients $<15$ months; administer while off immunosuppression (Table IV); ${ }^{2}$ Immunity refers to past diagnosis of varicella or herpes zoster, verified by a physician; documented receipt of 2-doses of vaccine 4-8 weeks apart; or serological evidence of immunity; ${ }^{f}$ Consider post-vaccination testing for adequacy (anti-HBs antibody $\geq 10 \mathrm{mIU} / \mathrm{mL}$ ) and administering higher $(20 \mu \mathrm{g})$ or additional doses

Both PCV7/10/13 and PPSV23 elicit satisfactory serological response, even when given during relapse or while on immunosuppressive agents [135]. Nevertheless, we suggest that the vaccine be preferably given during remission, and while on low or no immunosuppression. Antibody responses are ill-sustained in patients with recurrent relapses, justifying re-dosing with PPVS23 after 5 years if the disease remains active; more than 2doses of PPSV23 are not recommended [134,135].

\section{Varicella Vaccine}

In view of the risk of severe disease in immunocompromised patients, we recommend that patients with nephrotic syndrome receive two doses of the varicella vaccine, 4-8 weeks apart (Table V) $[134,138]$. Two doses result in seroconversion in $\sim 95 \%$ vaccinees; breakthrough varicella might occur in 2.2$7.3 \%$ children [142]. The vaccine was safe and immunogenic in 109 patients with nephrotic syndrome, 
including those receiving low-dose corticosteroids, in two prospective series $[143,144]$ and in an open-label RCT [145].

Severe varicella might follow infection in at-risk individuals exposed to persons with either varicella or herpes zoster. Multiple strategies for post-exposure prophylaxis are used to prevent viral transmission (Table VI) [124,133,134,138,146-149]. Unimmunized patients with nephrotic syndrome who are not immunosuppressed should receive the vaccine within 5days of exposure [124]. The risk of post-exposure varicella was reduced to one-third in children who were vaccinated following exposure, compared to those unimmunized (3 studies; $n=110 ; 23 \% v s .78 \%$ ) [147]. Healthy household contacts should also receive the vaccine to minimize the risk of infecting the patient. In patients in whom vaccination is contraindicated, the Center for Disease Control recommends administration of varicella zoster immune globulin (VARIZIG) within 10-d of exposure [148]. VARIZIG administration was associated with varicella in $<10 \%$ of 507 high-risk participants, including 231 immunosuppressed children [149]. In view of the low and variable titer of anti-VZV antibodies [150], intravenous immunoglobulin (IVIG) is not recommended [124,134]. If VARIZIG is not available, similar to guidelines from the American Academy of Pediatrics [124] and French Society of Pediatric Nephrology [138], we recommend administering oral acyclovir or valacyclovir for 7-days, starting 6-10 days after exposure, corresponding to the period of secondary viremia (Table VI).

\section{Influenza Vaccine}

Influenza accounts for $13 \%$ of all pneumonia, and $7 \%$ of severe pneumonia in children <5-yr-old [150,151].
Approximately 1 in 5 unvaccinated children are annually infected by influenza, of which one-half are symptomatic [152]. Given the risk of morbidity in immunosuppressed individuals, annual administration of the inactivated influenza vaccine is recommended for patients with nephrotic syndrome (Table V), and their household contacts $[124,130,138]$.

\section{Hepatitis B Vaccine}

Hepatitis B vaccination coverage rates in India are unsatisfactory, and $45 \%$ of 1-6 yr-old children are not vaccinated [153]. Compared to healthy children, fewer patients with nephrotic syndrome show seroprotective ( $\geq 10 \mathrm{mIU} / \mathrm{mL}$ ) antibody titers [154]; one-half of these patients seroconvert after vaccination [136,155]. Seroprotection was lower in patients with steroid resistance, and those on non-steroid therapies $[136,154,155]$. To overcome vaccine failure, we advise an accelerated schedule using twice the age-appropriate dose, and assessment of serological response to administer booster dose(s) (Table V) [156].

\section{GUIDELINE 8: TRANSITION OF CARE}

We recommend that patients with nephrotic syndrome who continue to have relapses in adolescence be transitioned into care by adult physicians.

(X)

\section{Rationale}

SSNS is a self-limiting illness, with the majority of patients outgrowing the illness by puberty. Review of information from multiple cohorts, with median followup of 4-30 yr, indicates that the frequency of relapses declines with age [3,4,157-159]. However, 5-42\% patients may continue to have active disease in adulthood. Risk factors for illness persisting beyond

Table VI Post-Exposure Management of Unimmunized Patients with Nephrotic Syndrome Exposed to Varicella ${ }^{a}$

\begin{tabular}{|c|c|c|c|}
\hline $\begin{array}{l}\text { Contraindication } \\
\text { to live vaccine }\end{array}$ & Strategy & Timing after exposure & Level of evidence \\
\hline No & Administer varicella vaccine & As soon as possible, $<5 \mathrm{~d}$ & $\mathrm{~A}[133,146,147]$ \\
\hline \multirow[t]{4}{*}{ Yes } & Options (in order of preference) & & \\
\hline & $\begin{array}{l}\text { Varicella zoster immunoglobulin (VARIZIG) }{ }^{c} \\
125 \text { IU per } 10 \mathrm{~kg} \text { body weight (maximum } 625 \mathrm{IU}) \\
\text { intramuscular }\end{array}$ & $\begin{array}{l}<10 \text { days; preferably } \\
<4 \text { days }\end{array}$ & B $[148,149]$ \\
\hline & $\begin{array}{l}\text { Oral acyclovir, } 80 \mathrm{mg} / \mathrm{kg} \text { in } 4 \text { divided doses (maximum } \\
3.2 \mathrm{~g} \text { ) daily for } 7 \text { days OR oral valacyclovir (if } \geq 3 \text {-mo-old), } \\
60 \mathrm{mg} / \mathrm{kg} \text { (maximum } 3 \mathrm{~g} \text { ) daily in } 3 \text { divided doses for } 7 \text { days }\end{array}$ & $\begin{array}{l}\text { Begin 6-10 d after } \\
\text { exposure }\end{array}$ & $\mathrm{C}[124,134,138]$ \\
\hline & Intravenous immune globulin, $400 \mathrm{mg} / \mathrm{kg}$ & $<10 \mathrm{~d}$ & $\mathrm{X}[124,134]$ \\
\hline
\end{tabular}

${ }^{a}$ More than 5 minutes of face-to-face contact with individual with varicella or zoster, while indoors; ${ }^{b}$ See Table IV; ${ }^{c}$ Available internationally from one manufacturer since 2006 when VZIG was discontinued (https://varizig.com/liquid-ordering_info.html), brands marketed in India include Vartiect-CP (Paviour Pharma). 
18 -yr of age include early age at onset, and frequently relapsing or steroid dependent course $[3,4,157,158]$.

Major infections, associated with relapses and intense immunosuppression, are the chief cause of hospitalization and mortality $(0-8 \%)[3,157,158]$. Kidney failure is uncommon $(<1 \%)$ in patients with SSNS. There is significant risk of short stature (15\%), obesity $(10 \%)$, hypertension (6-46\%), metabolic bone disease (9-63\%), diabetes mellitus $(2 \%)$, ocular complications $(10 \%)$, infertility and malignancies $[157,158,160]$. Psychosocial concerns, including school drop-out, unemployment and unstable relationships are common [161].

Given the risk of disease persistence and prevalence of complications, it is advised to transfer the care of adolescents with relapsing disease to 'adult' nephrologists by 18 year of age. National and international guidelines advocate for smooth transition, with emphasis on shared clinics and consideration of patient and parent perspectives [162].

\section{CONCLUSIONS}

The present guidelines, based on best available evidence and expert guidance, provide directions for evaluation and management of SSNS in children. Recommendations, proposed by the Indian Society of Pediatric Nephrology, in 2001 and 2008, have been revised based on systematic reviews, published studies and expert opinion. The management of frequent relapses continues to be challenging, with morbidities associated with the disease as well as therapies. Well-designed prospective studies are required to address issues related to therapy of the initial

\section{Table VII Areas for Clinical Studies in Steroid Sensitive} Nephrotic Syndrome

\section{Therapy of initial episode, relapse}

Optimal dose and duration of corticosteroid therapy in young $(<4-6$ years $)$ patients.

Optimal intensity of therapy with prednisolone (daily and alternate day dose and duration) to induce remission and reduce further risk of relapses.

\section{Management of frequent relapses}

Efficacy and safety of prednisolone administered on alternate days or daily; minimum effective dose.

Relative efficacy and safety of various immunosuppressive agents.

Efficacy and long-term safety of therapy with calcineurin inhibitors; lowest effective dose.

Efficacy and long-term safety of therapy with rituximab; optimal dosing strategy (redosing at relapses, sequential administration vs maintenance immunosuppression); safe cumulative dose threshold. episode and relapsing nephrotic syndrome (Table VII). We hope that the present guidelines will standardize therapies and improve the quality of care for patients with the disease.

Note: Supplementary material related to these recommedations is available with the online version at $w w w$.indianpediatrics.net Contributors: All authors were involved in review of literature, preparation of background document, drafting and critically revising the manuscript. All authors approved the final version of the manuscript.

Funding: Indian Council of Medical Research; Advanced Centre for Research in Pediatric Kidney Diseases [5/7/1090/2013RHN]; Department of Biotechnology, Government of India [BT/ PR11030/MED/30/1644/2016].

Competing interests: None stated.

\section{REFERENCES}

1. Noone DG, Iijima K, Parekh R. Idiopathic nephrotic syndrome in children. Lancet. 2018;392:61-74

2. Banh THM, Hussain-Shamsy N, Patel V, et al. Ethnic differences in incidence and outcomes of childhood nephrotic syndrome. Clin J Am Soc Nephrol. 2016;11:1760-8.

3. Tarshish P, Tobin JN, Bernstein J, Edelmann CM Jr. Prognostic significance of the early course of minimal change nephrotic syndrome: Report of the International Study of Kidney Disease in Children. J Am Soc Nephrol. 1997;8:769-76.

4. Sinha A, Hari P, Sharma PK, et al. Disease course in steroid sensitive nephrotic syndrome. Indian Pediatr. 2012;49:881-7.

5. Kim JS, Bellew CA, Silverstein DM, et al. High incidence of initial and late steroid resistance in childhood nephrotic syndrome. Kidney Int. 2005;68:1275-81.

6. Indian Pediatric Nephrology Group, Indian Academy of Pediatrics. Consensus Statement on Management of Steroid Sensitive Nephrotic Syndrome. Indian Pediatr 2001;38:975-86.

7. Indian Pediatric Nephrology Group, Indian Academy of Pediatrics, Bagga A, Ali U, Banerjee S, Kanitkar M, Phadke KD, Senguttuvan P, Sethi S, Shah M. Management of Steroid Sensitive Nephrotic Syndrome: Revised Guidelines. Indian Pediatr. 2008;45:203-14.

8. Guyatt GH, Oxman AD, Vist GE, et al; GRADE Working Group. GRADE: An emerging consensus on rating quality of evidence and strength of recommendations. BMJ. 2008;336:924-6.

9. Kidney Disease Improving Global Outcomes Expert Group on Glomerular Diseases. KDIGO Clinical Practice Guideline on Glomerular Diseases: Public Review draft. Accessed June 15, 2020. Available from https://kdigo.org/guidelines/gn/

10. Indian Society of Pediatric Nephrology. Revised Guidelines on Management of Steroid Resistant Nephrotic Syndrome. Indian Pediatr. 2021:S097475591600278 (online ahead of print).

11. American Academy of Pediatrics Steering Committee on Quality Improvement and Management. Classifying Recommendations for Clinical Practice Guidelines. Pediatrics. 2004;114:874-7.

12. Petersmann A, Müller-Wieland D, Müller UA, et al. Definition, classification and diagnosis of diabetes mellitus. Exp Clin Endocrinol Diabetes. 2019;127:S1-S7.

13. Khadilkar VV, Khadilkar AV. Revised Indian Academy of Pediatrics 2015 growth charts for height, weight and body mass index for 5-18-year-old Indian children. Indian J Endocrinol Metab. 2015;19:470-6.

14. Khadilkar V, Khadilkar A, Arya A, et al. Height velocity percentiles in Indian children aged 5-17 years. Indian Pediatr. 2019;56:23-8.

15. Sathiyamoorthy R, Kalaivani M, Aggarwal P, Gupta SK. Prevalence of pulmonary tuberculosis in India: A systematic review and metaanalysis. Lung India. 2020;37:45-52. 
16. National Strategic Plan for Tuberculosis Elimination 2017-2025. Available from: https://tbcindia.gov.in/WriteReadData/ NSP\%20Draft\%2020.02.2017\%201.pdf. Accessed November 1, 2020.

17. Batham A, Narula D, Toteja T, et al. Systematic review and metaanalysis of prevalence of hepatitis B in India. Indian Pediatr. 2007;44:663-74.

18. Lane BM, Cason R, Esezobor CI, Gbadegesin RA. Genetics of childhood steroid sensitive nephrotic syndrome: An update. Front Pediatr. 2019;7:8.

19. Uwaezuoke SN. The role of novel biomarkers in childhood idiopathic nephrotic syndrome: A narrative review of published evidence. Int J Nephrol Renovasc Dis. 2017;10:123-8.

20. Nephrotic syndrome in children: Prediction of histopathology from clinical and laboratory characteristics at time of diagnosis. A report of the International Study of Kidney Disease in Children. Kidney Int. 1978;13:159-65.

21. White RH, Glasgow EF, Mills RJ. Clinicopathological study of nephrotic syndrome in childhood. Lancet. 1970;1:1353-9.

22. Srivastava RN, Mayekar G, Anand R, Choudhry VP, Ghai OP, Tandon HD. Nephrotic syndrome in Indian children. Arch Dis Child. 1975;50:626-30.

23. Gipson DS, Massengill SF, Yao L, et al. Management of childhood onset nephrotic syndrome. Pediatrics. 2009;124:747-57.

24. Trautmann A, Vivarelli M, Samuel S, et al; International Pediatric Nephrology Association: IPNA Clinical Practice Recommendations for the Diagnosis and Management of Children with Steroid Resistant Nephrotic Syndrome. Pediatr Nephrol. 2020;35:1529-61.

25. Alshami A, Roshan A, Catapang M, et al; Pediatric Nephrology Clinical Pathway Development Team. Indications for kidney biopsy in idiopathic childhood nephrotic syndrome. Pediatr Nephrol. 2017;32:1897-905.

26. Rutjes N, Sinha A, Bagga A, et al. Outcome of steroid sensitive idiopathic nephrotic syndrome commencing after the age of 12 years. $45^{\text {th }}$ Annual Meeting of the European Society of Pediatric Nephrology, Krakow, Poland. Pediatr Nephrol. 2012;27:1704.

27. Gulati S, Sural S, Sharma RK, et al. Spectrum of adolescent-onset nephrotic syndrome in Indian children. Pediatr Nephrol. 2001;16:1045-8.

28. Webb NJ, Lewis MA, Iqbal J, Smart PJ, Lendon M, Postlethwaite RJ. Childhood steroid sensitive nephrotic syndrome: Does the histology matter? Am J Kidney Dis. 1996;27:484-8.

29. KDIGO Clinical Practice Guidelines. General principles in management of glomerular disease. KI Suppl. 2012;S2:S156-62.

30. Ishikura $\mathrm{K}$, Matsumoto $\mathrm{S}$, Sako $\mathrm{M}$, et al; Japanese Society for Pediatric Nephrology. Clinical practice guideline for pediatric idiopathic nephrotic syndrome 2013: Medical therapy. Clin Exp Nephrol 2015;19:6-33.

31. Lusco MA, Fogo AB, Najafian B, Alpers CE. AJKD atlas of renal pathology: Calcineurin inhibitor nephrotoxicity. Am J Kidney Dis. 2017;69:e21-2.

32. Liu F, Mao JH. Calcineurin inhibitors and nephrotoxicity in children. World J Pediatr. 2018;14:121-6.

33. Iijima K, Hamahira K, Tanaka R, et al. Risk factors for cyclosporineinduced tubulointerstitial lesions in children with minimal change nephrotic syndrome. Kidney Int. 2002;61:1801-5.

34. Sinha A, Sharma A, Mehta A, et al. Calcineurin inhibitor induced nephrotoxicity in steroid resistant nephrotic syndrome. Indian J Nephrol. 2013;23:41-6.

35. Fujinaga S, Kaneko K, Muto T, et al. Independent risk factors for chronic cyclosporine induced nephropathy in children with nephrotic syndrome. Arch Dis Child. 2006;91:666-70.

36. Delbet JD, Aoun B, Buob D, et al. Infrequent tacrolimus-induced nephrotoxicity in French patients with steroid-dependent nephrotic syndrome. Pediatr Nephrol. 2019;34:2605-8.

37. Nankivell BJ, Ng CH, O Connell PJ, Chapman JR. Calcineurin inhibitor nephrotoxicity through the lens of longitudinal histology: Comparison of cyclosporine and tacrolimus eras. Transplantation. 2016;100:1723-31.

38. Ishikura K, Yoshikawa N, Hattori S, et al; for Japanese Study Group of Renal Disease in Children. Treatment with microemulsified cyclosporine in children with frequently relapsing nephrotic syndrome. Nephrol Dial Transplant. 2010;25:3956-62.

39. Corwin HL, Schwartz MM, Lewis EJ. The importance of sample size in the interpretation of the renal biopsy. Am J Nephrol. 1988;8:85-9.

40. Pavlisko EN, Howell DN. The continued vital role of electron microscopy in the diagnosis of renal disease/dysfunction. Ultrastruct Pathol. 2013;37:1-8.

41. The primary nephrotic syndrome in children. Identification of patients with minimal change nephrotic syndrome from initial response to prednisolone. A report of the International Study of Kidney Disease in Children. J Pediatr. 1981;98:556-64.

42. Ehrich JH, Brodehl J. Long versus standard prednisone therapy for initial treatment of idiopathic nephrotic syndrome in children. Arbeitsgemeinschaft fur Padiatrische Nephrologie. Eur J Pediatr. 1993; 152:357-61.

43. Hodson EM, Willis NS, Craig JC. Corticosteroid therapy for nephrotic syndrome in children. Cochrane Database Syst Rev. 2007;4:CD001533.

44. Hahn D, Hodson EM, Willis NS, Craig JC. Corticosteroid therapy for nephrotic syndrome in children. Cochrane Database Syst Rev. 2015;3:CD001533.

45. Webb NJA, Woolley RL, Lambe T, et al; PREDNOS Collaborative Group. Long term tapering versus standard prednisolone treatment for first episode of childhood nephrotic syndrome: Phase III randomized controlled trial and economic evaluation. BMJ. 2019;365:11800.

46. Sinha A, Saha A, Kumar M, et al. Extending initial prednisolone treatment in a randomized control trial from 3 to 6 months did not significantly influence the course of illness in children with steroidsensitive nephrotic syndrome. Kidney Int. 2015;87:217-24.

47. Emma F, Montini G, Gargiulo A. Equations to estimate prednisone dose using body weight. Pediatr Nephrol. 2019;34:685-8.

48. Redlarski G, Palkowski A, Krawczuk M. Body surface area formulae: An alarming ambiguity. Sci Rep. 2016;6:27966.

49. Feber J, Al-Matrafi J, Farhadi E, Vaillancourt R, Wolfish N. Prednisone dosing per body weight or body surface area in children with nephrotic syndrome: Is it equivalent? Pediatr Nephrol. 2009;24:1027-31

50. Saadeh SA, Baracco R, Jain A, et al. Weight or body surface area dosing of steroids in nephrotic syndrome: Is there an outcome difference? Pediatr Nephrol. 2011;26:2167-71.

51. Hirano D, Fujinaga $S$. Two dosing regimens for steroid therapy in nephrotic syndrome. Pediatr Nephrol. 2014;29:325.

52. Raman V, Krishnamurthy S, Harichandrakumar KT. Body weightbased prednisolone versus body surface area- based prednisolone for induction of remission in children with nephrotic syndrome: a randomized, open-label, equivalence clinical trial. Pediatr Nephrol. 2016;31:595-604.

53. Basu B, Bhattacharyya S, Barua S, Naskar A, Roy B. Efficacy of body weight vs body surface area-based prednisolone regimen in nephrotic syndrome. Clin Exp Nephrol. 2020;24:622-9.

54. Ekka BK, Bagga A, Srivastava RN. Single- versus divided-dose prednisolone therapy for relapses of nephrotic syndrome. Pediatr Nephrol. 1997;11:597-9.

55. Schijvens AM, Ter Heine R, de Wildt SN, Schreuder MF. Pharmacology and pharmacogenetics of prednisone and prednisolone in patients with nephrotic syndrome. Pediatr Nephrol. 2019;34:389-403.

56. Aljebab F, Choonara I, Conroy S. Systematic review of the toxicity of short-course oral corticosteroids in children. Arch Dis Child. 2016;101:365-70. 
57. Liu D, Ahmet A, Ward L, et al. A practical guide to the monitoring and management of the complications of systemic corticosteroid therapy. Allergy Asthma Clin Immunol. 2013;9:30.

58. Lombel RM, Gipson DS, Hodson EM; Kidney Disease: Improving Global Outcomes. Treatment of Steroid-Sensitive Nephrotic Syndrome: New Guidelines from KDIGO. Pediatr Nephrol. 2013;28:415-26.

59. Abeyagunawardena AS, Thalgahagoda RS, Dissanayake PV, et al. Short courses of daily prednisolone during upper respiratory tract infections reduce relapse frequency in childhood nephrotic syndrome. Pediatr Nephrol. 2017;32:1377-82.

60. Yadav M, Sinha A, Khandelwal P, Hari P, Bagga A. Efficacy of lowdose daily versus alternate-day prednisolone in frequently relapsing nephrotic syndrome: An open-label randomized controlled trial. Pediatr Nephrol. 2019;34: 829-35.

61. Srivastava RN, Vasudev AS, Bagga A, Sunderam KR. Long-term, low-dose prednisolone therapy in frequently relapsing nephrotic syndrome. Pediatr Nephrol. 1992;6:247-50.

62. Hodson EM, Craig JC. In steroid sensitive nephrotic syndrome in children, is there clear evidence that steroids given every second day are more beneficial in terms of reducing relapse rate and side effects compared with half the dose given every day? Pediatr Nephrol. 2001;16:1159-60.

63. Mühlig AK, Lee JY, Kemper MJ, et al. Levamisole in children with idiopathic nephrotic syndrome: Clinical efficacy and pathophysiological aspects. J Clin Med. 2019;8:860.

64. Larkins NG, Liu ID, Willis NS, Craig JC, Hodson EM. Noncorticosteroid immunosuppressive medications for steroid-sensitive nephrotic syndrome in children. Cochrane Database Syst Rev. 2020;4:CD002290

65. Gruppen MP, Bouts AH, Jansen-van der Weide MC, et al; members of the Levamisole Study Group. A randomized clinical trial indicates that levamisole increases the time to relapse in children with steroidsensitive idiopathic nephrotic syndrome. Kidney Int. 2018;93: 510-8.

66. Vivarelli M, Emma F. Levamisole for children with nephrotic syndrome: New evidence for the use of an "old" drug. Kidney Int. 2019;95:25-8.

67. Jin Q, Kant S, Alhariri J, Geetha D. Levamisole adulterated cocaine associated ANCA vasculitis: Review of literature and update on pathogenesis. J Community Hosp Intern Med Perspect. 2018;8: 339-44.

68. Querfeld U, Weber LT. Mycophenolate mofetil for sustained remission in nephrotic syndrome. Pediatr Nephrol. 2018;33: 2253-65.

69. Jellouli M, Fitouhi S, Abidi K, et al. Mycophenolate mofetil in treatment of childhood steroid-dependent nephrotic syndrome. Tunis Med. 2016;94:221-5.

70. Sinha A, Puraswani M, Kalaivani M, Goyal P, Hari P, Bagga A. Efficacy and safety of mycophenolate mofetil versus levamisole in frequently relapsing nephrotic syndrome: An open-labelrandomized controlled trial. Kidney Int. 2019;95:210-8.

71. Gellermann J, Weber L, Pape L, Tonshoff B, Hoyer P, Querfeld U. Mycophenolate mofetil versus cyclosporin A in children with frequently relapsing nephrotic syndrome. J Am Soc Nephrol. 2013; 24:1689-97.

72. Tong K, Mao J, Fu H, et al. The value of monitoring the serum concentration of mycophenolate mofetil in children with steroiddependent/frequent relapsing nephrotic syndrome. Nephron. 2016;132:327-34

73. Hackl A, Cseprekal O, Gessner M, et al. Mycophenolate mofetil therapy in children with idiopathic nephrotic syndrome: Does therapeutic drug monitoring make a difference? Ther Drug Monit. 2016;38:274-9.

74. Sobiak J, Resztak M, Ostalska-Nowicka D, et al. Monitoring of mycophenolate mofetil metabolites in children with nephrotic syndrome and the proposed novel target values of pharmacokinetic parameters. Eur J Pharm Sci. 2015;77:189-96.

75. Mendizábal S, Zamora I, Berbel O, et al. Mycophenolate mofetil in steroid/cyclosporine-dependent/resistant nephrotic syndrome. Pediatr Nephrol. 2005;20:914-9.

76. Fujinaga S, Ohtomo Y, Umino D, et al. A prospective study on the use of mycophenolate mofetil in children with cyclosporinedependent nephrotic syndrome. Pediatr Nephrol. 2007;22:71-6.

77. Fujinaga S, Ohtomo Y, Hirano D, et al. Mycophenolate mofetil therapy for childhood-onset steroid dependent nephrotic syndrome after long-term cyclosporine: extended experience in a single center. Clin Nephrol. 2009;72:268-73.

78. Benz MR, Ehren R, Kleinert D, et al. Generation and validation of a limited sampling strategy to monitor mycophenolic acid exposure in children with nephrotic syndrome. Ther Drug Monit. 2019;41: 696-702.

79. Latta K, von Schnakenburg C, Ehrich JH. A meta-analysis of cytotoxic treatment for frequently relapsing nephrotic syndrome in children. Pediatr Nephrol. 2001;16:271-82.

80. Fu HD, Qian GL, Jiang ZY. Comparison of second-line immunosuppressants for childhood refractory nephrotic syndrome: A systematic review and network meta-analysis. J Investig Med. 2017;65:65-71.

81. Rivkees SA, Crawford JD. The relationship of gonadal activity and chemotherapy-induced gonadal damage. JAMA. 1988;259:2123-5.

82. Arslansoyu Camlar S, Soylu A, Kavukçu S. Cyclosporine in pediatric nephrology. Iran J Kidney Dis. 2018;12:319-30.

83. Hao GX, Song LL, Zhang DF, Su LQ, Jacqz-Aigrain E, Zhao W. Off-label use of tacrolimus in children with glomerular disease: Effectiveness, safety and pharmacokinetics. Br J Clin Pharmacol. 2020;86:274-84.

84. Sinha A, Bagga A, Gulati A, Hari P. Short-term efficacy of rituximab versus tacrolimus in steroid-dependent nephrotic syndrome. Pediatr Nephrol. 2012;27:235-41.

85. Fujinaga $\mathrm{S}$, Ohtomo $\mathrm{Y}$, Someya $\mathrm{T}$, et al. Is single-daily low-dose cyclosporine therapy really effective in children with idiopathic frequent-relapsing nephrotic syndrome? Clin Nephrol. 2008;69: 84-9.

86. Nakahata T, Tanaka H, Tsugawa K, et al. C1-C2 point monitoring of low-dose cyclosporin a given as a single daily dose in children with steroid-dependent relapsing nephrotic syndrome. Clin Nephrol. 2005;64:258-63.

87. Sinha A, Bagga A. Rituximab therapy in nephrotic syndrome: Implications for patients' management. Nat Rev Nephrol. 2013;9:154-69.

88. Kronbichler A, Kerschbaum J, Fernandez-Fresnedo G, et al. Rituximab treatment for relapsing minimal change disease and focal segmental glomerulosclerosis: A systematic review. Am J Nephrol. 2014;39:322-30.

89. Sinha A, Bhatia D, Gulati A, et al. Efficacy and safety of rituximab in children with difficult-to-treat nephrotic syndrome. Nephrol Dial Transplant. 2015;30:96-106.

90. Jacobs R, Langer-Jacobus T, Duong $M$, et al. Detection and quantification of rituximab in the human urine. J Immunol Methods. 2017;451:118-21.

91. Chan EY, Webb H, Yu E, et al. Both the rituximab dose and maintenance immunosuppression in steroid-dependent/frequentlyrelapsing nephrotic syndrome have important effects on outcomes. Kidney Int. 2020;97:393-401.

92. Tony HP, Burmester G, Schulze-Koops H, et al; GRAID investigators. Safety and clinical outcomes of rituximab therapy in patients with different autoimmune diseases: Experience from a national registry (GRAID). Arthritis Res Ther. 2011;13:R75.

93. Tang Z, Li X, Wu S, et al. Risk of hepatitis B reactivation in HBsAgnegative/HBcAb-positive patients with undetectable serum HBV DNA after treatment with rituximab for lymphoma: A meta- 
analysis. Hepatol Int. 2017;11:429-33.

94. Khojah AM, Miller ML, Klein-Gitelman MS, et al. Rituximabassociated hypogammaglobulinemia in pediatric patients with autoimmune diseases. Pediatr Rheumatol Online J. 2019;17:61.

95. Parmentier C, Delbet JD, Decramer S, et al. Immunoglobulin serum levels in rituximab-treated patients with steroid-dependent nephrotic syndrome. Pediatr Nephrol. 2020;35:455-62.

96. Colucci M, Carsetti R, Serafinelli J, et al. Prolonged impairment of immunological memory after anti-CD20 treatment in pediatric idiopathic nephrotic syndrome. Front Immunol. 2019;10:1653.

97. Kaku Y, Ohtsuka Y, Komatsu Y, et al; Japanese Society for Pediatric Nephrology. Clinical Practice Guideline for Pediatric Idiopathic Nephrotic Syndrome 2013: General Therapy. Clin Exp Nephrol. 2015;19:34-53.

98. Hoorn EJ, Ellison DH. Diuretic resistance. Amer J Kidney Dis. 2017;69:136-42.

99. Büyükavci MA, Çivilibal M, Elevli M, Selçuk Duru HN. Hypo- and hypervolemic edema in children with steroid sensitive nephrotic syndrome. Turk J Med Sci. 2015;45:178-83.

100. Gurgoze MK, Gunduz Z, Poyrazoglu MH, Dursun I, Uzum K, Dusunsel R. Role of sodium during formation of edema in children with nephrotic syndrome. Pediatr Int. 2011;53:50-6.

101. Meena J, Bagga A. Current perspectives in management of edema in nephrotic syndrome. Indian J Pediatr. 2020;87:633-40.

102. Marzuillo P, Guarino S, Apicella A, et al. Assessment of volume status and appropriate fluid replenishment in the setting of nephrotic syndrome. J Emerg Med. 2017;52:e149-52.

103. Keenswijk W, Ilias MI, Raes A, et al. Urinary potassium to urinary potassium plus sodium ratio can accurately identify hypovolemia in nephrotic syndrome: A provisional study. Eur $\mathrm{J}$ Pediatr. 2018:177:79-8

104. Matsumoto H, Miyaoka Y, Okada T, et al. Ratio of urinary potassium to urinary sodium and the potassium and edema status in nephrotic syndrome. Intern Med. 2011;50:551-5.

105. Kapur G, Valentini RP, Imam AA, Mattoo TK. Treatment of severe edema in children with nephrotic syndrome with diuretics alone: A prospective study. Clin J Am Soc Nephrol. 2009;4:907-13.

106. Ray EC, Rondon-Berrios H, Boyd CR, Kleyman TR. Sodium retention and volume expansion in nephrotic syndrome: implications for hypertension. Adv Chronic Kidney Dis. 2015;22:179-84.

107. Hinrichs GR, Jensen BL, Svenningsen P. Mechanisms of sodium retention in nephrotic syndrome. Curr Opin Nephrol Hypertens. 2020;29:207-12.

108.Park SJ, Shin JI. Complications of nephrotic syndrome. Korean J Pediatr. 2011;54:322-8.

109. Nalcacioglu H, Ozkaya O, Baysal K, et al. The role of bioelectrical impedance analysis, NT-ProBNP and inferior vena cava sonography in the assessment of body fluid volume in children with nephrotic syndrome. Nefrologia. 2018;38:48-56.

110. Taneja K, Kumar V, Anand R, Pemde HK. Normative data for IVC diameter and its correlation with the somatic parameters in healthy Indian children. Indian J Pediatr. 2018;85:108-12.

111. Abraham B, Megaly M, Sous M, et al. Meta-analysis comparing torsemide versus furosemide in patients with heart failure. Am J Cardiol. 2020;125:92-9.

112.Elwell RJ, Spencer AP, Eisele G. Combined furosemide and human albumin treatment for diuretic-resistant edema. Ann Pharmacother. 2003;37:695-700.

113. Dharmaraj R, Hari P, Bagga A. Randomized cross-over trial comparing albumin and frusemide infusions in nephrotic syndrome. Pediatr Nephrol. 2009;24:775-82.

114.Ho JJ, Adnan AS, Kueh YC, Ambak NJ, Van Rostenberghe H, Jummaat $F$. Human albumin infusion for treating edema in people with nephrotic syndrome. Cochrane Database Syst Rev. 2019;7:CD009692.

115. Alfakeekh K, Azar M, Sowailmi BA, et al. Immunosuppressive burden and risk factors of infection in primary childhood nephrotic syndrome. J Infect Public Health. 2019;12:90-4.

116. Mantan M, Singh S. Infection associated relapses in children with nephrotic syndrome: A short-term outcome study. Saudi J Kidney Dis Transpl. 2019;30:1245-53.

117. Wei CC, Yu IW, Lin HW, Tsai AC. Occurrence of infection among children with nephrotic syndrome during hospitalizations. Nephrology (Carlton). 2012;17:681-8.

118. Kumar M, Ghunawat J, Saikia D, Manchanda V. Incidence and risk factors for major infections in hospitalized children with nephrotic syndrome. J Bras Nefrol. 2019; 41:526-33.

119. Ajayan P, Krishnamurthy S, Biswal N, Mandal J. Clinical spectrum and predictive risk factors of major infections in hospitalized children with nephrotic syndrome. Indian Pediatr. 2013;50:779-81.

120. Yamamoto R, Imai E, Maruyama S, et al. Incidence of remission and relapse of proteinuria, end-stage kidney disease, mortality, and major outcomes in primary nephrotic syndrome: The Japan Nephrotic Syndrome Cohort Study (JNSCS). Clin Exp Nephrol. 2020;24:52640.

121. Sadarangani M. Protection against invasive infections in children caused by encapsulated bacteria. Front Immunol. 2018;9:2674.

122. Solomkin JS, Mazuski JE, Bradley JS, et al. Diagnosis and management of complicated intra-abdominal infection in adults and children: Guidelines by the Surgical Infection Society and the Infectious Diseases Society of America. Clin Infect Dis. 2010;50:133-6

123. Shriner A, Wilkie L. Pediatric cellulitis: A red-hot concern. Pediatr Ann. 2017;46:e265-9.

124. Kimberlin DW, Brady MT, Jackson MA, Long SS (Eds.). Red Book: 2018 Report of the Committee on Infectious Diseases (31st ed.), American Academy of Pediatrics, Itasca, IL. Accessed October 2, 2020. Available from: http://search.ebscohost.com/login.aspx? direct $=$ true $\&$ scope $=$ site $\& d b=n l e b k \& d b=$ nlabk $\& A N=1809323$

125. Wu HM, Tang JL, Cao L, Sha ZH, Li Y. Interventions for preventing infection in nephrotic syndrome. Cochrane Database Syst Rev. 2012;2012:CD003964.

126. MacDonald NE, Wolfish N, McLaine P, Phipps P, Rossier E. Role of respiratory viruses in exacerbations of primary nephrotic syndrome. J Pediatr. 1986;108:378-82.

127. Dossier C, Sellier-Leclerc AL, Rousseau A, et al. Prevalence of herpesviruses at onset of idiopathic nephrotic syndrome. Pediatr Nephrol. 2014;29:2325-31.

128. Leuvenink R, Aeschlimann F, Baer W, et al. Clinical course and therapeutic approach to varicella zoster virus infection in children with rheumatic autoimmune diseases under immunosuppression. Pediatr Rheumatol Online J. 2016;14:34.

129. Gershon AA, Breuer J, Cohen JI, et al. Varicella zoster virus infection. Nat Rev Dis Primers. 2015;1:15016.

130. Committee on Infectious Diseases. Recommendations for prevention and control of influenza in children, 2019-2020. Pediatr. 2019;144:e20192478.

131. Kronbichler A, Gauckler P, Windpessl M, et al. COVID-19: Implications for immunosuppression in kidney disease and transplantation. Nat Rev Nephrol. 2020;16:365-7.

132. Vasudevan A, Mantan M, Krishnamurthy S, et al; Indian Society of Pediatric Nephrology. Managing children with renal diseases during COVID-19 pandemic. Indian Pediatr. 2020;57:641-51.

133. Balasubramanian S, Shah A, Pemde HK, et al; IAP Advisory Committee on Vaccines and Immunization Practices, 2018-19. Indian Academy of Pediatrics (IAP) Advisory Committee on Vaccines and Immunization Practices (ACVIP) Recommended Immunization Schedule (2018-19) and Update on Immunization for Children Aged 0 through 18 Years. Indian Pediatr. 2018;55: 1066-74.

134. Centers for Disease Control and Prevention. Epidemiology and prevention of vaccine-preventable diseases. Hamborsky J, Kroger 
A, Wolfe S, eds. 13th ed. Washington D.C. Public Health Foundation, 2015; Available from: https://www.cdc.gov/vaccines/ pubs/pinkbook/index.html. Accessed October 2, 2020.

135. Goonewardene ST, Tang C, Tan LT, et al. Safety and efficacy of pneumococcal vaccination in pediatric nephrotic syndrome. Front Pediatr. 2019;7:339.

136. Yýldýz N, Sever L, Kasapçopur Ö, Çullu F, Arýsoy N, Çalýpkan S. Hepatitis B virus vaccination in children with steroid sensitive nephrotic syndrome: Immunogenicity and safety? Vaccine. 2013;31:3309-12.

137. Banerjee S, Dissanayake PV, Abeyagunawardena AS. Vaccinations in children on immunosuppressive medications for renal disease. Pediatr Nephrol. 2016;31:1437-48.

138. Boyer O, Baudouin V, Bérard É, et al. Vaccine recommendations for children with idiopathic nephrotic syndrome. Nephrol Ther. 2020;16:177-83.

139. Ishimori S, Kamei K, Ando T, et al. Influenza virus vaccination in children with nephrotic syndrome: Insignificant risk of relapse. Clin Exp Nephrol. 2020;24:1069-76.

140. McIntyre P, Craig JC. Prevention of serious bacterial infection in children with nephrotic syndrome. J Paediatr Child Health. 1998:34:314-7.

141. Lucero MG, Dulalia VE, Nillos LT, et al. Pneumococcal conjugate vaccines for preventing vaccine-type invasive pneumococcal disease and $X$-ray defined pneumonia in children less than two years of age. Cochrane Database Syst Rev. 2009;2009:CD004977.

142. Newman AM, Jhaveri R. Myths and misconceptions: Varicellazoster virus exposure, infection risks, complications, and treatments. Clin Ther. 2019;41:1816-22.

143. Alpay H, Yildiz N, Onar A, Temizer H, Ozçay S. Varicella vaccination in children with steroid-sensitive nephrotic syndrome. Pediatr Nephrol. 2002;17:181-3.

144. Kamei K, Miyairi I, Ishikura K, et al. Prospective study of live attenuated vaccines for patients with nephrotic syndrome receiving immunosuppressive agents. J Pediatr. 2018;196:217-22.e1.

145. Furth SL, Arbus GS, Hogg R, Tarver J, Chan C, Fivush BA; Southwest Pediatric Nephrology Study Group. Varicella vaccination in children with nephrotic syndrome: A report of the Southwest Pediatric Nephrology Study Group. J Pediatr. 2003;142:145-8.

146. Lachiewicz AM, Srinivas ML. Varicella-zoster virus post-exposure management and prophylaxis: A review. Prev Med Rep. 2019;16:101016.

147. Macartney K, Heywood A, McIntyre P. Vaccines for post exposure prophylaxis against varicella (chickenpox) in children and adults. Cochrane Database Syst Rev. 2014;6:CD001833.

148. Centers for Disease Control and Prevention. Updated recommendations for use of VariZIG-United States, 2013. Morb Mortal Wkly Rep. 2013;62:574-6.

149. Levin MJ, Duchon JM, Swamy GK, Gershon AA. Varicella zoster immune globulin (VARIZIG) administration up to $10 \mathrm{~d}$ after varicella exposure in pregnant women, immunocompromised participants, and infants: Varicella outcomes and safety results from a large, open-label, expanded-access program. PLoS One. 2019;14:e0217749.

150. Paryani SG, Arvin AM, Koropchak CM, et al. Comparison of varicella zoster antibody titers in patients given intravenous immune serum globulin or varicella zoster immune globulin. J Pediatr. 1984;105:200-5.

151. Malosh RE, Martin ET, Ortiz JR, Monto AS. The risk of lower respiratory tract infection following influenza virus infection: A systematic and narrative review. Vaccine. 2018;36:141-7.

152. Somes MP, Turner RM, Dwyer LJ, Newall AT. Estimating the annual attack rate of seasonal influenza among unvaccinated individuals: A systematic review and meta-analysis. Vaccine. 2018;36:3199-207.

153. Khan J, Shil A, Mohanty SK. Hepatitis B vaccination coverage across India: Exploring the spatial heterogeneity and contextual determinants. BMC Public Health. 2019;19:1263.

154. Neupane N, Krishnamurthy S, Jagadisan B, Dhodapkar R. Hepatitis $\mathrm{B}$ seroprotection in pediatric nephrotic syndrome. Indian Pediatr. 2019;56:659-662.

155. Mantan M, Pandharikar N, Yadav S, Chakravarti A, Sethi GR. Seroprotection for hepatitis B in children with nephrotic syndrome. Pediatr Nephrol. 2013;28:2125-30.

156. Das S, Ramakrishnan K, Behera SK, Ganesapandian M, Xavier AS, Selvarajan S. Hepatitis B vaccine and immunoglobulin: Key concepts. J Clin Transl Hepatol. 2019;7:165-71.

157. Hjorten R, Anwar Z, Reidy KJ. Long-term outcomes of childhood onset nephrotic syndrome. Front Pediatr. 2016;4:53.

158. Marchel DM, Gipson DS. Adult survivors of idiopathic childhood onset nephrotic syndrome. Pediatr Nephrol. 2020 Nov 6; DOI: 10.1007/s00467-020-04773-3 [Online ahead of print]

159. Carter SA, Mistry S, Fitzpatrick J, et al. Prediction of short- and longterm outcomes in childhood nephrotic syndrome. Kidney Int Rep. 2019;5:426-34.

160. Lee JM, Kronbichler A, Shin JI, Oh J. Review on long-term nonrenal complications of childhood nephrotic syndrome. Acta Paediatr. 2020;109:460-70.

161. Mehta M, Bagga A, Bajaj G, Srivastava RN. Behavior problems in nephrotic syndrome. Indian Pediatr. 1995;32:1281-6.

162. Watson AR, Harden P, Ferris M, Kerr PG, Mahan J, Ramzy MF. Transition from Pediatric to Adult Renal Services: A Consensus Statement by the International Society of Nephrology and the International Pediatric Nephrology Association. Pediatr Nephrol. 2011;26:1753-7.

\section{ANNEXURE I}

\section{Expert Group of Indian Society of Pediatric Nephrology}

Participants: Anil Vasudevan, Bengaluru; Abhijeet Saha, New Delhi; Aditi Sinha, New Delhi; Aliza Mittal, Jodhpur; Amarjeet Mehta, Jaipur; Arpana Iyengar, Bengaluru; Arpita Gogoi, Dibrugarh; Anand S Vasudev, New Delhi; Pankaj Hari, New Delhi; Ranjeet Thergaonkar, Mumbai; Priyanka Khandelwal, New Delhi; Girish C Bhatt, Bhopal; Indira Agarwal, Vellore; Jitendra K Meena, New Delhi; Jyoti Sharma, Pune; Kanika Kapoor, New Delhi; Kamran Afzal, Aligarh; Kanav Anand, New Delhi; Karalanglin Tiewsoh, Chandigarh; Kirtisudha Mishra, New Delhi; M Ashraf, Srinagar; Manish Kumar, New Delhi; Manisha Sahay, Hyderabad; Mukta Mantan, New Delhi; OP Mishra, Varanasi; PK Pruthi, New Delhi; Rajiv Sinha, Kolkata Shobha Sharma, New Delhi; Subal Pradhan, Cuttack; Sudha Ekambaram, Chennai; Susan Uthup, Thiruvananthapuram; Sanjeev Gulati, New Delhi; Saroj K Patnaik, New Delhi; Sriram Krishnamurthy, Puducherry; Suprita Kalra, New Delhi; Sushmita Banerjee, Kolkata; Vinay Agarwal, New Delhi; Sumantra Raut, Kolkata; Arvind Bagga, New Delhi, India.

Experts: Uma Ali, Mumbai; Kumud Mehta, Mumbai; Madhuri Kanitkar, New Delhi; Amit K Dinda, New Delhi; Geetika Singh, New Delhi; Kishore D Phadke, Bengaluru; BR Nammalwar, Chennai; RN Srivastava, New Delhi. 